\title{
The Effectiveness of Industrial Policy in Developing Countries: Causal Evidence from Ethiopian Manufacturing Firms
}

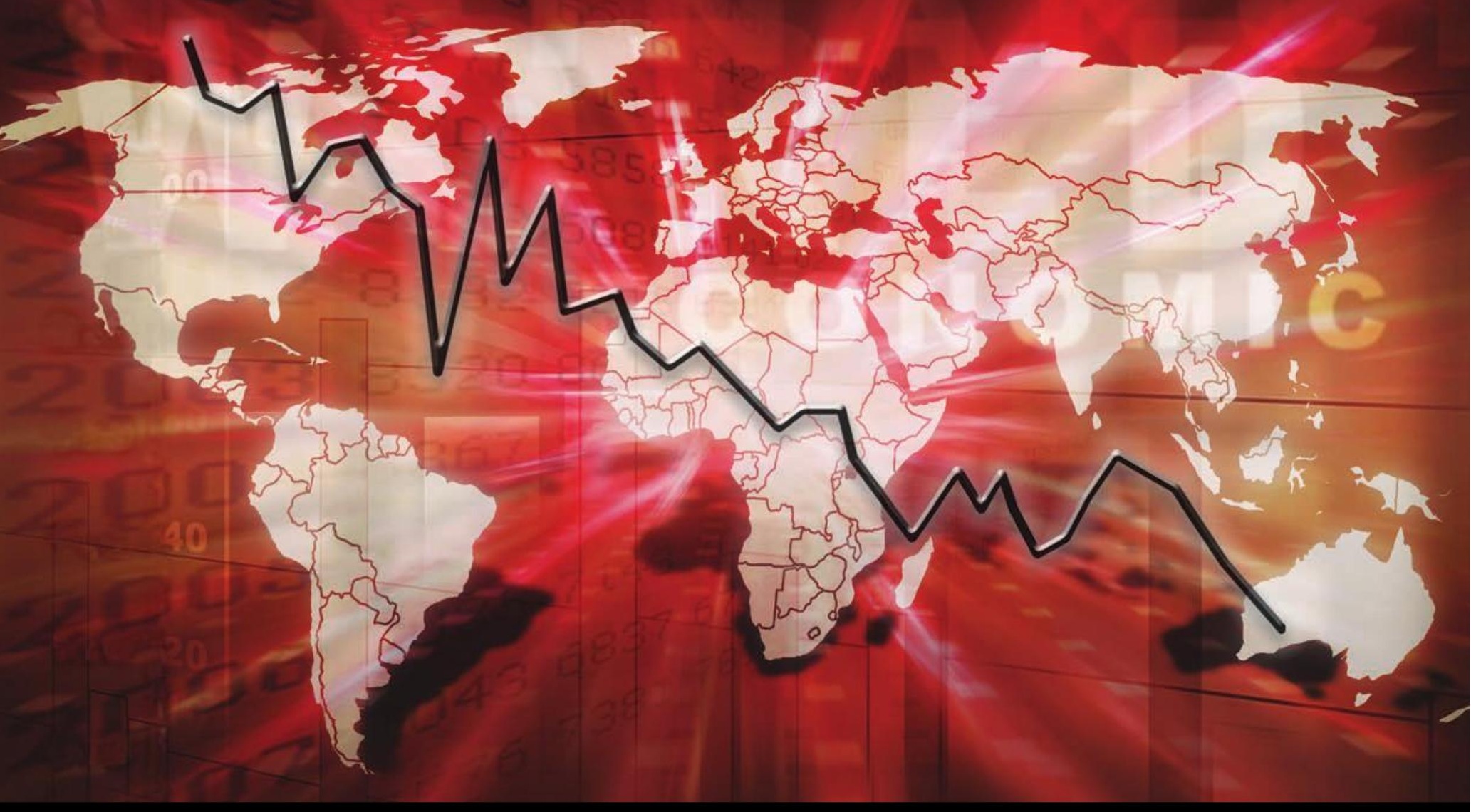

Tewodros Makonnen Gebrewolde, University of Leicester James Rockey, University of Leicester 


\title{
The Effectiveness of Industrial Policy in Developing Countries: Causal Evidence from Ethiopian Manufacturing Firms
}

Tewodros Makonnen Gebrewolde

University of Leicester

James Rockey

University of Leicester

\begin{abstract}
Prioritizing the growth of particular sectors or regions is often part of LDC growth strategies. We study a prototypical example of such policies in Ethiopia, exploiting geographic and sectoral variation in the form and scale of the policy for identification. Using product-level data on Ethiopian manufacturing firms we show that the policy was unsuccessful: There was no improvement in productivity, productive assets, or employment. The policy failed due to its negative effects on productivity of the entry of new firms and existing firms diversifying. Moreover, subsidised loans and tax-breaks led to an increase in capital but not in machinery.
\end{abstract}

Keywords: Industrial Policy, Ethiopia, Manufacturing.

JEL-Codes: H25, H81, O14, O25

Corresponding author email: james.rockey@le.ac.uk. We thank Martin Foureaux Koppensteiner, Sourafel Girma, and Jochen Mierau for their comments. We also thank seminar participants at the CSAE Conference 2015; the $13^{\text {th }}$ International Conference on the Ethiopian Economy; Royal Economic Society Sussex; Leicester; Nottingham; Queen's Belfast; and the Centre Emile Bernheim, Solvay Brussels School. Any errors are ours alone. 
It is thus that every system which endeavours, either, by extraordinary encouragements to draw towards a particular species of industry a greater share of the capital of the society than what would naturally go to it, or, by extraordinary restraints, to force from a particular species of industry some share of the capital which would otherwise be employed in it, is, in reality, subversive of the great purpose which it means to promote. It retards, instead of accelerating the progress of the society towards real wealth and greatness; and diminishes, instead of increasing, the real value of the annual produce of its land and labour. Smith (1776)

Despite Adam Smith's scepticism, the provision of subsidies and tax-breaks to particular industries has long been a favoured tool of governments hoping to steer and accelerate the development of their economy. This is particularly true of the governments of the Least Developed Countries (LDCs) (see, Rodrik, 2009). Such subsidies are a particular form of Industrial Policy (IP) - one that is extremely prevalent but poorly understood. This paper recasts Smith's claim as a question: is this form of IP effective? It provides the first causal analysis of IP in an LDC and in particular it studies whether the governments of LDCs may improve economic performance through the use of targeted subsidies and tax-breaks. Such policies reflect an important strain of thought in Development Economics; the 'big-push' arguments originally due to Rosenstein-Rodan (1943) and rejuvenated by Murphy et al. (1989). This tradition argues that such encouragement of activity in specific sectors and places can lead to sufficient scale and agglomeration economies to deliver sustained growth. We study a prototypical IP introduced by the Ethiopian Government as part of its growth strategy in 2002. In common with many such policies, the Ethiopian policy provided for a series of targeted tax-breaks, and other support including concessionary loans. Sectoral and geographic variation in the scale and form of the policy provide for a natural experiment that we exploit to identify causal estimates. We find that it did not lead to improvements in the productivity or scale of existing businesses, and that whilst it led to the entry of new, lower productivity businesses, this did not lead to any any 
accompanying agglomeration externalities.

That it failed is particularly disappointing as there are reasons to believe the potential benefits of IP will be larger in LDCs than elsewhere. It is also disappointing because there are also reasons to think that the costs of an unsuccessful policy are also high. Indeed, many of the theoretical arguments for industrial policy, such as those of Bulow and Summers (1986), Rebelo (1991) and Rodrik (2009), depend on imperfections in product, labour, and capital markets that can be expected to be larger in LDCs. Equally, the concerns that such imperfections are hard to identify and address are perhaps more plausible in LDCs. Yet, there is a lack of econometric evidence one way or the other. This paper addresses this deficit, and provides the first micro-econometric analysis of an industrial policy in an LDC. One of the complications of understanding the effects of an industrial policy is that any given policy can be expected to have several countervailing consequences. We formalise these different consequences with a simple analytical framework in which there are both direct effects on firms' productivity, capital, and employment levels, but also spillovers between firms. We then take this to a rich product-level dataset on the universe of Ethiopian manufacturing firms to tease apart these different consequences. These data allow us to understand not only the impact on firms' growth, but also on the entry of firms, and the entry of existing firms into new product lines. Crucially, they also allow us to exploit the intersection of variations in the sectoral and geographical eligibility criteria, to obtain causal estimates from a difference-in-difference-in-difference estimator. In line with the theory, we find evidence that the direct impact of the policy on productivity is negative, and that whilst there are positive spillover effects, these are to small to compensate for the direct costs. We further show that whilst the policy does encourage additional investment out of retained profits, the productivity of capital falls. Drilling down further into the data reveals that this investment is concentrated on only indirectly productive assets, such as buildings and vehicles, rather than directly productive machinery. We interpret this a form of savings in the face of high prevailing inflation rates rather than investment in production per se. The policy's failure to generate 
additional employment can also be explained by this lack of investment in machinery. A calculation of the costs of the policy suggests that the policy was expensive, with forgone tax revenues alone equivalent to $0.5 \%$ of GDP or $5 \%$ of annual Government Spending - for comparison, the entire manufacturing sector accounts only for $5 \%$ of GDP.

Whilst we focus on Ethiopia, the policy we study is similar in form to those implemented in several other countries in Sub-Saharan Africa (SSA). Table 1 summarises the structure of the Industrial Policy of a selection of eight SSA countries as described by Marti and Ssenkubuge (2009). The table separates IP into three categories: Trade related policies, the literature on which is discussed below; Sector Specific Support, which is the focus of this paper; and inducements for Foreign Direct Investments, itself the subject of a large literature. Each of these policies is then categorised on the basis of whether it has a substantial Tax or Duty/Tariff component, and whether other forms of government support were provided. The table reveals the broad consistency in the form of IP in these eight countries. Specifics of the policies are provided in Table A6 in the Appendix. Focussing on sectoral support, all of the countries other than Cameroon provided additional support to specific sectors. Cameroon provided support solely by exempting certain sectors from tax, while Ghana and Kenya employ both strategies. Ethiopia is unusual in that it provides different reductions in tax depending on location. The precise form of the 'other' support varies; but it normally involves, as in Ethiopia, a combination of concessionary loans, alongside infrastructure and training support. That the Ethiopian policy also offers tax-breaks based on location means that we are also able to test the efficacy of tax incentives. Thus, the Ethiopian policy we study is both representative of policies implemented elsewhere. The combination of geographic tax-breaks and sectoral support allows us to test the full range of policies. For both of these reasons, our finding that it was ineffective may therefore have implications for the design of policy in other LDCs.

This paper builds on previous work that estimates the causal effects of similar combinations of tax-breaks and subsidies designed to stimulate output in economically depressed regions of rich nations. Busso et 
Table 1: Summary of Industrial Policy in Eight Subsaharan Africa Countries.

\begin{tabular}{rcccccc}
\hline \multicolumn{1}{c}{ Country } & \multicolumn{2}{c}{ Trade } & \multicolumn{2}{c}{ Sectoral } & \multicolumn{2}{c}{ FDI } \\
\hline & Duty \& Tarrif & Other & Tax & Other & Tax & Other \\
Botswana & $\checkmark$ & & & $\checkmark$ & $\checkmark$ & $\checkmark$ \\
Cameroon & $\checkmark$ & $\checkmark$ & $\checkmark$ & & & $\checkmark$ \\
Ethiopia & $\checkmark$ & $\checkmark$ & $\checkmark$ & $\checkmark$ & $\checkmark$ & $\checkmark$ \\
Ghana & $\checkmark$ & & $\checkmark$ & $\checkmark$ & $\checkmark$ & $\checkmark$ \\
Kenya & $\checkmark$ & $\checkmark$ & $\checkmark$ & $\checkmark$ & $\checkmark$ & $\checkmark$ \\
Rwanda & $\checkmark$ & & & $\checkmark$ & $\checkmark$ & $\checkmark$ \\
South Africa & $\checkmark$ & $\checkmark$ & & $\checkmark$ & & $\checkmark$ \\
Uganda & $\checkmark$ & & & $\checkmark$ & $\checkmark$ & $\checkmark$ \\
\hline
\end{tabular}

Source: Marti and Ssenkubuge (2009)

al. (2013) study the US Federal Empowerment Zone (EZ) program and find that it increased employment without costs in efficiency or effects on prices. Similarly, Criscuolo et al. (2016) find in their study of the impact of the EU Regional Selective Assistance scheme on UK firms that both employment and investment increased. Moreover, they too find that this happens at little cost to productivity. On the other hand Gobillon et al. (2012), studying the French EZ programme, find that the effects are small and transitory. Moreover, Neumark and Kolko (2010), who study a similar Californian policy, find it too to be ineffective.

As well as a difference in context between countries such as the the US (Busso et al., 2013), France (Gobillon et al., 2012), or the UK (Criscuolo et al., 2016) and that of countries such as Ethiopia, there is also a necessary difference in emphasis. This may be seen through the lens of the analysis of Albouy (2009). He exploits the fact that the incidence of US federal taxation is unevenly distributed to provide evidence that local tax rates are a long-run determinant of output and employment levels. This suggests a mechanism through which EZ zones can boost local output. In the US, such policies represent a small fraction of GDP and thus need not pay for themselves, but rather can be seen as an efficient form of redistribution. On the other hand, the Ethiopian policy is, in relative terms, expensive. This means, that even if a policy of tax-breaks for particular sectors of Ethiopian Manufacturing Industry 
is expected, given the previous evidence, to be successful, it should come at a cost elsewhere in terms of the necessary additional taxation. Thus, what it means for IP to be effective is different in one of the LDCs, such as Ethiopia, and a rich nation, such as France or the U.S., and our focus on TFP reflects that. ${ }^{1}$ Put differently, in the LDC context, effective IP is IP that can pay for itself.

Our focus on productivity is in common with the literature on the another form of IP, protectionism and infant industries, which also has often focussed on less-developed countries. Harrison (1994) revisiting Krueger and Tuncer (1982) argued that sectors of Turkish manufacturing that had enjoyed more protection had (in fact) also exhibited faster productivity growth. By now, there is increasing support for the opposite conclusion. Topalova and Khandelwal (2011) provide causal evidence that reduced tariffs in India led to improved firm-level productivity. Goldberg et al. (2010) show that the same reduction in tariffs led to an increase in the number of products available. Blonigen (2015) looks at the impact of protecting an important sector, in his case steel, on other sectors. He finds that there are large costs for sectors using steel. Of particular relevance for this paper is that he finds the costs of the policy are highest in LDCs. Harrison and RodríguezClare, Andrés (2010) review both the theoretical and empirical literature and suggest that there is little evidence that Industrial Policy based on tariffs, quotas and subsidies is effective. They do suggest, however, that more subtle policy may be successful. Nunn and Trefler (2010) provide quantitative evidence of such subtlety. They show that countries in which the tariff structure favours skill-intensive industries grow faster, but that three-quarters of this effect is due to the endogeneity between tariff-structures and domestic rent-seeking. Along similar lines, Aghion et al. (2015) argue theoretically and empirically that protectionist policies can be productivity-enhancing when they are targeted at sectors that are already competitive, or when they are designed to encourage competition. They present evidence from Chinese

\footnotetext{
${ }^{1}$ IP could also be effective if it led to growth through the reallocation of capital to more productive activities. In Section 6 we test for this and find no evidence of such effects.
} 
manufacturing firms that the interaction of sector-level competition and subsidy is positive and significant. This paper contributes to this literature by providing micro-econometric evidence based on extremely rich data about the effects of tax-breaks in an LDC. We are able to isolate the causal mechanisms through which the policy affects firms. This provides insights into why the policy we study was less successful than that examined by Aghion et al. (2015). One reading of our findings in the context of this literature is that we provide new evidence for why 'blunt' policies are ineffective.

The paper is organized as follows. Section 2 introduces a simple analytical framework with which to organise our ideas and to derive the hypotheses that the remainder of the paper will test. Section 3 discusses the particular policy we study and outlines key features of the Ethiopian context. Section 4 introduces the data we employ, Section 5 specifies the empirical strategy we use to identify the causal effects of the policy, and Section 6 presents the results. Section 7 presents calculations of the cost of the policy. Section 8 closes the paper.

\section{Analytical Framework}

To fix ideas and clarify our hypotheses, it useful to construct a simple analytical framework. We extend that of Criscuolo et al. (2012) who focus on an expression for the cost of capital owing to Hall and Jorgenson (1967), King (1975), and Ruane (1982). They use this to study the implications of EU Regional Assistance for employment and capital utilization. We extend this approach to obtain predictions for the effects of the policy on TFP. In particular, our framework formalises the intuition that IP will lower average productivity as previously nonviable firms will enter the market. It also embodies the notion that, particularly in LDCs, that there may be increasing returns to scale as increased output and competition can improve average productivity through spill-overs and other agglomeration externalities.

We consider a highly stylised economy comprised of a continuum of firms, each able to produce $A_{i} \in\left(0, A^{+}\right)$units of output given $K$ units of capital and $L$ of labour. These units are normalised such that $\int_{i} K d i=$ 
$\int_{i} L d i=1$. Firms are otherwise identical and each firm must pay capital and wage costs of $\rho K+\psi L$, where $\rho>0$ and $\psi>0$ and Value Added Tax rate of $1>\tau>0$. The cost of capital is given by the Hall and Jorgenson (1967) formulation:

$$
\rho=\delta+\frac{r(1-\theta \tau)}{1-\tau}
$$

where $1>\theta>0$ is the depreciation allowance, $r>0$ is the interest rate, and $1>\delta>0$ the depreciation rate. In equilibrium, not all firms choose to produce, and in particular, firm $i$ produces iff it makes weakly positive profit:

$$
\Pi_{i}=\tau A_{i}-(\rho K+\psi L) \geq 0 .
$$

We denote the $A_{i}$ that satisfies this condition exactly as $A^{*}$. Every firm has a CES production technology $Y_{i}=f\left(A_{i}, K, L\right)$ with elasticity of substitution $\sigma . A_{i}$ is the firm specific TFP term given by the product

$$
A_{i}=B_{i}\left(A^{+}-A^{*}\right)^{\phi},
$$

where $B_{i}>0$ is the level of TFP of firm $i$ that would obtain in the absence of agglomeration externalities and $\phi>0$ implies that there are positive agglomeration externalities. It follows that total output is given by:

$$
Y=\int_{A^{*}}^{A^{+}} Y_{i} d i
$$

and average productivity is similarly:

$$
\bar{A}=\frac{1}{A^{+}-A^{*}} \int_{A^{*}}^{A^{+}} A_{i} d i .
$$

For simplicity, we treat the funding for any tax-reduction as being obtained from elsewhere, in the context of Ethiopia perhaps from development assistance. It follows immediately that a tax-relief policy has the following consequences: 
1. Output increases:

$$
\frac{\partial Y}{\partial \tau}<0
$$

2. If $\phi<3$ average productivity decreases:

$$
\frac{\partial \bar{A}}{\partial \tau}>0
$$

If $\phi>3$ then the spillover effect is sufficiently large that the additional agglomeration effect due to the new firms entering more than offsets the effects of their lower average productivity, and $\frac{\partial Y}{\partial \tau}>0$. This is a very simple statement of the notion common to many of traditional 'big-push' arguments for IP: If $\phi$ is sufficiently large then average productivity will increase, and the policy will have had an unambiguously positive impact. Whilst, caution is necessary in drawing quantitative conclusions from such a simple model that here agglomeration externalities need to be cubic suggests that alone they may often be insufficient. ${ }^{2}$

3. Unemployment falls. As in Criscuolo et al. (2012), we can use the chain-rule to write the elasticity of employment as the product of the elasticity of capital with respect to the tax and the elasticity of employment with respect to the cost of capital:

$$
\eta_{L}=\frac{\partial \rho}{\partial \tau} s_{K}(\sigma-\eta)=\frac{r(-1+\theta)}{(-1+\tau)^{2}} s_{K}(\sigma-\eta)
$$

We assume that capital and labour are substitutes, $0<\sigma<1$, and that product markets are price-elastic, $\eta>1$. Inspection of both terms on the RHS reveals them to be negative, implying that unemployment falls if the cost of capital falls.

4. Capital utilisation increases. This is given by $\frac{\partial \rho}{\partial \tau}<0$ calculated above, and implies capital utilisation increases if the tax rate falls. It is useful to note the intimate relationship between capital utilisation and employment here. If one goes up, so does the other. Thus, an increase in capital utilisation should imply an increase

\footnotetext{
${ }^{2}$ To see this, substitute (2) and (3) into (5) and solve for $\phi$ such that $\frac{\partial \bar{A}}{\partial \tau}=0$.
} 
in employment. On the other-hand, if for some reason an increase in capital were mis-invested in a low-productivity asset then we should not expect much increase in employment. We shall see that this is the case below.

The overall consequences of the policy will thus depend on the distribution of the (latent) productivities of firms in the economy, the relative importance of agglomeration externalities, and the skill with which additional capital is invested. We shall see that in the case we study, that agglomeration externalities are insufficient to offset the lower productivity of entering firms, and that capital tends to be directed towards assets that are more fungible rather than productive.

Here we ignore how the tax-breaks are financed. This is reasonable if they are paid for by cuts to non-productive expenditure elsewhere, from additional foreign-aid, or deficit spending. The generalisation to a general-equilibrium model, where the policy must be financed from other taxation, or cuts in productive government expenditure in the tradition of Barro (1990) produces the same qualitative predictions at the cost of some additional complication.

\section{Industrial Policy in Ethiopia}

Between 1974 and 1991, Ethiopia endured decades of drought, war, and political instability under the communist regime known as the Derg. During this era there was little industrial production and private enterprise was discouraged. This changed in 1994 with the promulgation of a new constitution. Since then, Ethiopia has been following an industrial development strategy named Agricultural Development Led Industrialization (ADLI). It focusses on improving agricultural productivity to both release labour for the industrial sector and increase agricultural incomes to serve as a strong market for the industrial sector's products. The overall strategy has so-far comprised three five-year plans since 2000. The first plan was called the Sustainable Development and Poverty Reduction Plan (SDPRP) and began in 2000. ${ }^{3}$

\footnotetext{
${ }^{3}$ The second five-year plan is called the Plan for Accelerated and Sustainable Development to End Poverty (PASDEP) and ran for the next five years. The final phase,
} 
The subject of this paper is specific aspects of the SDPRP to enhance private sector development. Specifically, in 2002, the government announced a revised schedule of incentives and tax-breaks. The strategy was explicitly designed to encourage manufacturing sectors that were labour intensive and that utilised Ethiopian agricultural products (see, Ministry of Finance and Economic Development, 2002). Firms were eligible for tax breaks as follows:

- If a firm exports $>50$ percent or more or supplies $>75$ percent to an exporter it received 4 years income tax exemption.

- Exports $<50$ percent it recieved 2 years income tax exemption.

- Companies not around Addis Ababa gained 1 additional year of tax exemption.

- All enterprises were eligible to customs duty exemption on capital goods.

These investment incentives do not differentiate between specific industries. They do, however, differentiate firms based on location and export volume. The number of firms with such export volume is small and these firms are almost exclusively long-standing and government owned. Instead, we focus our attention on the eligibility of firms more than $100 \mathrm{~km}$ outside the centre of Addis-Ababa for an additional tax-break. Ethiopia is divided in 9 administrative regions. This division is based on ethnicity. These regions are further divided into 68 administrative zones which are in turn divided into 560 woredas (districts). Figure 1 plots these different regions and a central circle depicts the $100 \mathrm{~km}$ zone that defines our treatment. This shows that even though Addis-Ababa is the key locus of economic activity, this area is small given the size of the country. When we come to test for agglomeration externalities, we will treat woredas as our unit of analysis.

In addition to these general investment incentives, and in line with the development plans discussed above, specific sectors were targeted the Growth and Transformation Plan (GTP) finished in 2015. 
Figure 1: Ethiopia: Administrative Divisions

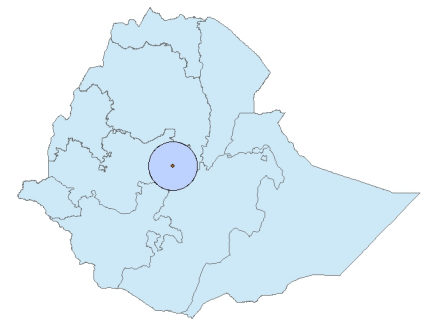

(a) Region

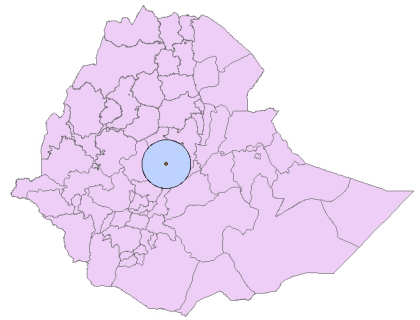

(b) Zone

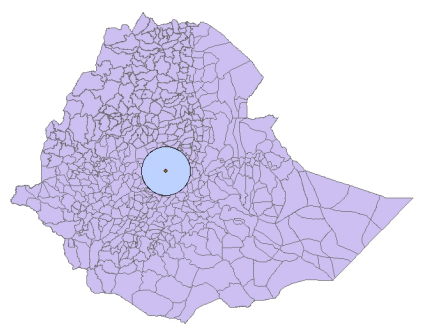

(c) Woredas

for direct support. The selection of these sectors is mainly based on their linkages to the agricultural sector, labour intensity and export potential. These sectors are: textiles and garments; meat and leather products; agro-processing; and construction. The details of this support are described in Appendix C. The structure of the policy and support offered is outlined in Figure 2. Treated sectors had access to concessionary loans, as well as initiatives to improve the supply of trained workers and other technology support. Our treatment is the intersection of the two arms of the policy - being outside Addis-Ababa and in a supported sector. By focusing on those firms that have received the most support we are giving the policy the best chance of being successful. That some of the sector-specific support is specifically designed to boost productivity, and thus likely to offset the predictions of declining productivity outlined in Section 2, improves these chances further. 


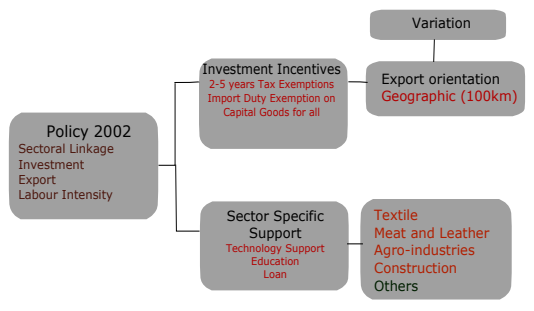

\subsection{Identification}

So that estimates of the policy's effectiveness are not biased upwards, we need to be sure that the policy was not targeted at firms most likely to benefit from it. Similarly, to avoid the concern of Rodrik (2009) that estimates may be biased downwards because aid goes to firms that most need it, we must be sure that the policy was also not targeted on this basis. Inspection of the policy proclamation (Ministry of Finance and Economic Development (2002)) shows that the overall objective of these measures is clear: it is to increase the linkages between agriculture and industry; to increase employment, and to increase exports. Thus, the sectors targeted were chosen solely on the basis of whether they make use of Ethiopian agricultural produce, or are labour intensive. It is clear that all of the targeted sectors; Meat and Leather, Textiles, AgroBusiness, and Construction fit this description. Importantly, none of them involves a product where Ethiopia may be expected to have a particular competitive advantage (or disadvantage). Thus, whilst the government must be keen to boost productivity there is no evidence that the choice of targeted sectors was made on the basis of maximizing TFP growth. ${ }^{4}$ Indeed, such a strategy of 'picking winners' is always fraught with difficulty, and particularly so given the context of Ethiopia at the turn of the century. Moreover, the reverse strategy of supporting losers is not consistent with the Ethiopian political context, or affordable given its budget constraints.

\footnotetext{
${ }^{4}$ There is also no evidence that these sectors were chosen for political economy reasons, and we have no evidence that there was systematic corruption in the delivery of the policy.
} 
Inspection of a map of the region around Addis-Ababa shows that the $100 \mathrm{~km}$ threshold is outside of the city and of no-obvious geographical importance - it clearly reflects the usual preference for round numbers than any particular economic or geographic reality. ${ }^{5}$ There are also relatively few firms near the threshold that might be expected to relocate. Secondly, property rights are technically all held by the Government in Ethiopia and thus the opportunity of firms to relocate is extremely limited. Thus, there is no reason to suspect that the choice of threshold geographic threshold was endogenous. Finally, one might be concerned that the firms subject to the geographic treatment are systematically different. There is little reason to believe this to be the case as most firms are engaged in low value added production using homogenous agricultural produce as inputs. Moreover, we include firm fixed effects and in the Appendix show that our results are robust to controlling for region-specific time trends. Thus, we can be clear that both arms of the policy and their intersection are exogenous.

\section{Data}

The data used in this study were obtained from the Ethiopian Large and Medium Scale Manufacturing Enterprises Census that is conducted annually by the Central Statistics Agency of Ethiopia. It contains the universe, and is hence an unbalanced panel, of firms for 14 years from 1996-2010. Initially, there are close to 600 firms in 1996. By 2010, there are around 1900. The firms are categorised into 54 industrial classification (ISIC) codes. Table A7 in the Appendix reports the average number of firms in each category over the period.

As well as being available for all firms, the data are extremely rich, containing detailed information on both the establishment and ownership details of each firm. We make use of much of this information, and summarise the information we use below:

- Ownership: Gender of the proprietors, and the proportion of a firm's capital in public, private, or foreign ownership.

\footnotetext{
${ }^{5}$ Indeed, our results are robust to the use of an $80 \mathrm{~km}$ or $100 \mathrm{~km}$ threshold.
} 
- Establishment: Detailed information on the month and year of establishment as well as a firm's initial capital are available.

- Employment: Classified by gender, salary group and occupation on a quarterly basis. Information on wages and other benefits for workers is also included.

- Products: Data are on up to 12 products. This includes the unit price, beginning stock, production quantity and production value, and we use these data to construct our output index and productivity measures. Data on sales and exports are also available at the product level.

- Investments: A firm's assets are aggregated into different categories such as fixed assets, furniture, machinery and vehicles. The levels of each are detailed with the beginning stock, annual changes and ending stock.

- Intermediate inputs: These are at the level of the firm rather than the product. They include unit price, quantity, value, source (local versus imported) of the input.

- Expenses: Production expenses, such as utilities, energy, and tax, are available at the firm level.

Importantly, as discussed below, these data contain detailed quantity information about both quantities of products produces and the quantities of the inputs used to do so. This, unusual level of detail allows us to understand precisely how the policy affected treated firms. Table 2 provides the usual summary of our key variables. In the rightmost column, to provide additional intuition about the complexity, scale, and nature of the manufacturing firms we study, we also describe a particular firm chosen to be representative of the median Ethiopian manufacturing firm.

We can see that the average firm employs 186 people, the median firm 113. Yet, the level of output is high compared to both the amount of capital mean, \$2.42 Million (22 Million Br), median firm \$0.44 Million and even more so compared to the book value of the machinery used 
which on average is only $\$ 0.37$ Million, and $\$ 77,000$ in the median firm. This, along with the high ratio of the Value of Output to the cost of the intermediate inputs, reflects the labour-intensive nature of production. Of the \$4,000 capital per worker only around one tenth of that is in machinery, with the rest being inventories of (cheap) raw materials. These small amounts of capital are perhaps more surprising given that these are not small firms, and often they are not new - the sample firm we consider is slightly older than average at 20 years. The oldest firm is by now over a hundred years old, but firms that pre-date the downfall of the Derg will have been previously, and often still are, completely state owned.

\section{Methodology}

A key feature of the Ethiopian economy in the period we study is its rapid growth and even more rapid inflation. This dynamic environment is a useful laboratory for studying IP, but also necessitates particular care in the estimation of firm productivities. De Loecker (2011) emphasised that using data on (deflated) sales rather than production quantities could lead to bias if errors in the assumed prices were correlated with the choice of inputs. Fortunately, we are able to avoid these concerns as we use data describing both input and output quantities (and prices).

De Loecker et al. (2016) draws attention to two further sources of bias. Firstly, "bias stemming from the unobserved allocation of inputs across products within multi-product firms"; and secondly unobserved quality differentiation in inputs. They address the first by focusing on single-product firms thus removing the potential for bias. They address the second by deriving a control function for input prices which is incorporated directly into the productivity regressions.

We are able to address the first concern by similarly restricting our sample to single-product firms, although we do so only to demonstrate that the policy had significant negative effects on these firms. To preserve sample-size, and because we are interested in all of the firms treated by the policy - we give the policy the benefit of focusing on analysing the whole sample. The second source of bias is alleviated as 
we use directly observed input quantities. Moreover, we also observe the full details of firms' initial capital (and its composition) and subsequent investment decisions. Thus, we may be confident - particularly for single product firms - that our results are not driven by unobserved price variation.

The dynamic nature of the Ethiopian economy during the period at hand means that the concerns about simultaneity and selection, emphasised by Olley and Pakes (1996) (OP), are of particular concern. Whilst the importance of selection means that the OP estimator is to be preferred our results are robust to using a variety of alternatives. Firstly, all of our results are robust to alternative measures of output based on a value-index, in which sales are deflated by regional CPI trends to (try to) capture variations in inflation. Secondly, while we focus on firms' bestselling products, we also obtain similar results using Laspeyres indices for the four or eight best-sellers.

The production function estimation results are presented in Table 3. The preferred estimates in column 1 show a near constant returns to scale production function. Perhaps surprising is that Ethiopian firms, although labour intensive, have a lower marginal product of capital than of labour with the marginal product of labour being 0.53 in the preferred specification compared to 0.27 for capital. But, this is consistent with the literature. ${ }^{6}$ The estimator of Levinsohn and Petrin (2003) does not allow for selection but may perform better if investment is often zero. We report results using this alternative estimator, as well as GMM and fixed effects estimators.

The effect of the policy can be recovered by regressing our productivity estimates on dummy variables describing the two arms of the policy described in Figure 2, and their interaction. We augment this difference in difference in difference (D3) regression with firm fixed effects, and a

\footnotetext{
${ }^{6}$ We might expect the low levels of capital in Ethiopian firms to lead to high marginal products. But, De Loecker et al. (2016) obtain similar results for Indian firms at the product level. Firm level estimates by Bigsten et al. (2004) obtained similar results for Kenya, Ghana, Cameroon and Zimbabwe. Siba et al. (2012) also studies Ethiopian firms, and finds the marginal product of capital to be below 10 percent.
} 
vector of time-varying controls. Thus, our benchmark specification is:

(6) $y_{i t}=\tau_{0} d_{t}+\tau_{1}\left(d_{i} \cdot d_{t}\right)+\tau_{2}\left(d_{j} \cdot d_{t}\right)+\tau_{3}\left(d_{i} \cdot d_{j} \cdot d_{t}\right)+\beta \mathbf{X}_{\mathbf{i t}}+\mu_{i}+\epsilon_{i t}$,

where $y_{i t}$ represents TFP and later will alternatively be employment, investment and product diversification. $d_{t}$ captures the introduction of the policy and is defined as $d_{t}=\mathbf{1}$ [year $\left.\geq 2002\right]$. The sectoral treatment is captured with $d_{i}=\mathbf{1}[s \in$ Agro-industry, Construction, Meat and Leather, Textiles]. The geographic treatment is given by $d_{j}=\mathbf{1}$ [distance $\geq$ 100]. $\mathbf{X}_{\mathbf{i t}}$ is a vector of controls discussed below. Note that we cannot disentangle the average effect of sector and location $d_{i}$ and $d_{j}$ from the firm fixed effects. Thus, the coefficients of interest are the difference in difference estimates: $\tau_{1}, \tau_{3}$, and particularly the difference in difference in difference estimate: $\tau_{3}$. If, as indicated in Section 3 the policy has been successful we expect positive and significant coefficients. Following Bertrand et al. (2004) our standard errors are clustered by firm.

\section{Results}

This section begins by showing that the empirical evidence supports the central prediction of the analytical framework outlined in Section 2 - that there should be no productivity improvement associated with the policy. We then demonstrate the reasons for this result. We begin by showing the effects of how the entry of new firms lowered average productivity, and moreover, that these additional firms failed to generate agglomeration externalities. We then show the other ways in which the policy altered (existing) firms' behaviour shedding light on why we find no positive effect on existing firms. We see that the policy led to additional diversification in existing firms, also lowering productivity. Given the tax-breaks and subsidised loans available to firms are designed to reduce the cost of capital and facilitate investment, we drill down in to the form of the additional capital investments caused by the policy. These were in stores of value rather than productive machinery and we relate that to the volatile economic environment faced by firms. In doing so we note that the policy is also unsuccessful if 
success were defined in terms of employment or capital growth as in Busso et al. (2013) or Gobillon et al. (2012).

\section{Overall Effect of Policy}

We begin by considering the overall impact of the policy. We estimate Equation (6) with TFP as the dependent variable. $X_{i t}$ includes each firm's age; whether it government owned; (log) investment; product diversification; and competition following Aghion et al. (2015). We measure both competition and diversification using Herfindahl-Hirschman indices. Let $p_{i t j}$ denote the share of product $j$ of the output of firm $i$ in year $t$. Then, Diversification is calculated at the firm level as Divers ${ }_{i t}=\sum_{j} p_{i t j}^{2}$. Industry level competition is calculated using firms' shares of industry output $o_{i t s}$ : Compet Cos $_{i}=\sum_{i} o_{i t s}^{2}$.

It is conventional to present specifications that are as demanding as possible in order to emphasise the robustness of the results. Here, we present specifications that are clearly as flattering to the policy as possible to make it clear that the lack of any evidence for a positive effect of the policy is not due to the choice of estimation strategy. In particular we include a simple post-treatment dummy rather than a stochastic time-trend, or region specific trends, although doing so does not alter our results. Similarly, errors are clustered only at the firm level, although results are robust to clustering by firm and year, etc. Most importantly, we focus much of our analysis on existing firms. As we will show, and as expected, new firms are (substantially) less-productive than firms that pre-date the treatment. But, it might be argued that, in the Ethiopian context or generally, boosting the productivity of existing firms is sufficiently important to make the the proliferation of lower productivity firms unimportant. By focusing our attention on existing firms we take this form of argument seriously and by doing so rule out that the policy was successful for this (or other) subgroups.

The results are presented in column 1 of Table 4 . We see that there is no overall effect of the policy as the coefficient on the interaction of the two arms of the policy $\tau_{3}$ is negative, small, and imprecise. Both $\tau_{2}$, the effect of the sectoral support policies, and $\tau_{1}$, the effect of the 
geographically determined tax break, while positive, are also close to zero and imprecise. That the coefficients on both arms of the policy are negative is a finding that we see consistently across the different specifications reported (excluding column 5). Similarly consistent is the finding that the coefficient on the interaction is positive. This is as would be expected as additional policies to lower the costs of capital presumably have diminishing effects. The combined impact of the policy is negative $\left(\tau_{1}+\tau_{2}+\tau_{3}=-0.03\right.$ and insignificant. Column 3 reports results considering only single-product firms à la De Loecker et al. (2016). Now, the magnitude of the negative coefficients on the two arms of the policy are larger, but still insignificant. The interaction term $\tau_{3}$ is also larger but insignificant. As is the combined effect $\tau_{1}+\tau_{2}+\tau_{3}=-0.3$ which we cannot reject is equal to zero. To address concerns that these negative and imprecise estimates are due to the choice of productivity measure, Columns $4-6$ report results for the same specification with alternative measures of TFP as the dependent variable introduced above. Column 4 reports results based on the method of Levinsohn and Petrin (2003). This method will perform better if investment is often zero in a given year. ${ }^{7}$ Results obtained using GMM and Fixed Effects estimators are reported in Columns 5 and 6 . In all but two cases the estimates of $\tau_{1}-\tau_{3}$ are insignificant and close to zero, $\tau_{2}$ is significant and negative when using the LP estimator, and significant and positive when using GMM. Thus, we may be confident that there is no evidence whatsoever that the evidence for the failure of the policy is an artefact of the choice of productivity estimator. Columns 7 and 8 of Table 4 address a second concern - that government owned firms may respond differently to the treatment. Column 7 reports results calculated using only private firms, Column 8 only government firms. In both cases, there is no effect of the policy. We also repeated this analysis for individual sectors (Table A2 in Appendix A) - the comparison is now a given treated sector compared to all untreated sectors - again there is no effect of (any part of) the policy. Table A1 shows that alternative specifications additionally including individual year effects, fixed effects for Regions or Zones, and or their interaction give similar results. Taken

\footnotetext{
${ }^{7}$ In fact, in our data investment is almost always non-zero.
} 
together, we can be confident that that the lack of an effect of the policy on TFP is robust to the choice of productivity estimators, fixed-effects, government ownership, and sector. This results is also consistent with the lack of any positive effect on productivity found in more developed countries.

Other results are also in line with our expectations: firms in more competitive industries (Compet $t_{t s}$ lower) are substantially more productive, although the estimate is imprecise in our preferred specification. Similarly more diversified (Divers $s_{i t}$ lower) firms are less productive. Given we include firm fixed-effects, the coefficient on firm age should be interpreted as the effect on productivity of having been in business for longer. This coefficient is positive in our preferred specification, but close to zero, and not robust to other choices of estimator or output index. Government Ownership measures the impact, given our fixed effects, of becoming government owned. The effect is positive but sensitive to the choice of productivity estimator.

\section{Decrease in Productivity Due to Entry}

The framework in Section 2 suggests that one consequence of a reduction in the tax rate will be to allow firms to enter the market that would have otherwise been unprofitable. If this is the case, then we might expect average TFP to fall as a consequence of the policy even if output is increasing. That is, that the effect of the policy on TFP due to variation on the extensive margin will be negative. To take this hypothesis to the data we note that an alternative estimator of (6) would be a pseudopanel estimator as discussed by Verbeek (2008). Estimators of this type are most commonly applied to datasets that are a repeated crosssection, and for which it is possible to identify subsets of the population with membership fixed over time - 'cohorts'. The data are then the set of averages of each variable by period and cohort observations, and a conventional estimation procedure (but with suitable corrections to the variance matrix) may be employed. Our strategy hinges on the fact that this approach will be inconsistent to the extent that there is entry by new firms. In our D3 framework, the excess entry of new 
firms in treated sectors and their impact on average productivity will be given by the difference between the pseudo-panel estimates and the firm-level D3 estimates. More precisely, averaging (6) by sector and Zone, and indexing these cohorts as $c \in\{1, \ldots, C\}$ with asterisks denoting population quantities (see, Deaton, 1985) we have:

(7) $\bar{y}_{c t}^{*}=\tau_{1}\left(d_{c}^{*} \times d_{t}^{*}\right)+\tau_{2}\left(d_{j}^{*} \times d_{t}^{*}\right)+\tau_{3}\left(d_{c}^{*} \times d_{j}^{*} \times d_{t}^{*}\right)+\gamma d_{t}^{*}+\beta \bar{X}_{i t}^{*}+\mu_{c}^{*}+\epsilon_{c t}^{*}$.

For clarity, we rewrite this using $\mathbf{Z}=\left[d_{c} d_{t} d_{j} X_{i t} \mu_{c}\right]$ and $\Lambda$ as the associated vector of coefficients. Moffitt (1993) showed that $\Lambda$ can be estimated using the interaction of cohort and time dummies as instruments. This makes the requirements for the consistency of the estimator clear - if the composition of the cohorts is not fixed then this is equivalent to the exclusion assumption being violated. ${ }^{8}$ Thus, assuming the measurement error is distributed as follows:

$$
\left(\begin{array}{l}
\bar{y}_{c t}-y_{c t}^{*} \\
\overline{\mathbf{Z}}_{c t}-\mathbf{Z}_{c t}^{*}
\end{array}\right) \sim \text { i.i.d. }\left[\left(\begin{array}{l}
0 \\
0
\end{array}\right),\left(\begin{array}{cc}
\sigma_{00} & \sigma^{\prime} \\
\sigma & \Sigma
\end{array}\right)\right]
$$

then, the estimator employed is:

$$
\tilde{\Lambda}=\left(M_{z z}-\tau \hat{\Sigma}\right)^{-1}\left(m_{z y}-\tau \hat{\sigma}\right)
$$

where:

$$
\begin{aligned}
M_{z z} & =\frac{1}{C T} \sum_{c=1}^{C} \sum_{t=1}^{T}\left(\bar{z}_{c t}-\bar{z}_{c}\right)\left(\bar{z}_{c t}-\bar{z}_{c}\right)^{\prime} \\
m_{z y} & =\frac{1}{C T} \sum_{c=1}^{C} \sum_{t=1}^{T}\left(\bar{z}_{c t}-\bar{z}_{c}\right)\left(\bar{y}_{c t}-\bar{y}_{c}\right) .
\end{aligned}
$$

Given our sample is relatively large, and contains the universe of manufacturing firms, it is reasonable to expect $\beta^{\Delta}=\tilde{\Lambda}-\hat{\beta} \approx 0$ if there were no firm entry. Thus $\beta^{\Delta}>0$ (conversely, $\beta^{\Delta}<0$ ) implies entering firms are more (less) productive than existing firms. Standard

\footnotetext{
${ }^{8}$ If the productivities did not vary over time then the instrument relevance assumption would also be violated.
} 
errors are obtained via the bootstrap. Column 2 of Table 4 presents the results and shows that the productivity impact of firm entry to be negative and significant as suggested by the theory. To see this, note that $\beta_{\tau^{1}}^{\Delta}+\beta_{\tau^{2}}^{\Delta}+\beta_{\tau^{3}}^{\Delta}=-2.53$, which is significant at all conventional levels. Interestingly, firms entering only due to the geographical treatment are more productive on average than other new firms. Whether, this reflects a positive effect of the policy or some other factor is unclear. Notably, a calculation of the the average impact of the geographical treatment across both treated and untreated sectors shows it to be equal to -0.75 , suggesting an overall negative effect of the treatment. Note, that whilst productivity has fallen, output has increased. In the long-run, the presence of additional low-productivity firms may eventually impede growth, but the associated increase in output may be important in the short-run. However, the cost estimates presented in Section 7 suggest that this output increase has come at a substantial fiscal cost.

\section{Indirect Increases in Productivity Due to Spillovers}

As described in Section 2, one margin on which IP might improve productivity is through spill-over effects. That is, if there are more or larger companies operating in an industry there may be more innovations to emulate, downwards pressure on input prices, for instance, thus leading to faster TFP growth. This is particularly true at Ethiopia's current level of development where production techniques often lag significantly behind those used in richer countries but are improving rapidly. Thus, the importation of new techniques and innovation may both be expected to be common. The framework in Section 2 suggests that if $\phi>3$ then $\frac{\partial \bar{A}}{\partial \tau}>0$ and the policy would thus raise the productivity of both treated and untreated firms approximately equally, meaning our DDD strategy would identify no effect.

To estimate the extent of agglomeration externalities we consider the effects of the presence of treated firms on nearby firms in untreated sectors. We do this by exploiting the rich geographic detail of the data and contrast productivity in untreated sectors in those Zones with few treated firms to those with more. We generate a geographic 
proximity variable for each non-treated firm measured by the number of treated firms in the same Zone, $N_{z t}$. For ease of interpretation $N_{z t}$ is standardized, and thus the coefficient $\kappa$ describes the percentage impact on productivity of a standard deviation increase. We include Zone and year fixed effects, $\psi_{t}$ and $\phi_{z}$, and a vector of controls $\mathbf{X}_{\mathbf{i t}}$ as in (6). Thus $\kappa$ is identified using the within variation of firm productivities as the number of treated firms with their zone varies. Our regression model is then:

$$
y_{i t}=\kappa N_{z t}+\beta \mathbf{X}_{\mathbf{i t}}+\phi_{z}+\psi_{t}+\mu_{i}+\epsilon_{i t}
$$

We find, as Column 1 of Table 4 reveals, that there is evidence for a small but positive effect on existing firms in untreated sectors. Specifically, a 1 standard deviation increase in the number of treated firms increases the productivities of firms in other sectors by $0.15 \%$. However, when we also consider entering firms in Column 2, this effect is smaller and less precise. ${ }^{9}$ Thus, whilst there is some evidence of agglomeration externalities for existing firms, there is no evidence that these would be sufficient to offset the deleterious effects of the policy on average productivity. There are several reasons why spill-over effects may not be larger. ${ }^{10}$ Ferracci et al. (2014) find evidence, in the rather different context of the French labour market, for the opposite mechanism - that large-scale training programmes in a given local labour market may lead to crowding-out effects. Here, an equivalent explanation might focus on the limited ability of local markets to absorb additional production. Alternatively, it could be that the low density of manufacturing in Ethiopia itself limits the scale of agglomeration effects. Evidence for these explanations would not alter our finding of the policies ineffectiveness, but might suggest that a similar policy might work better in a more industrialised country.

\footnotetext{
${ }^{9}$ These findings are robust to a variety of alternative specifications of (11).

${ }^{10}$ Blonigen (2015) considers the effect of IP targeting steel-producers on users of steel and finds a negative effect on their export competitiveness. Here, however, the treated sectors are by design those that use largely bulky agricultural products, producing products for domestic consumption so we should not necessarily expect this form of negative spillover.
} 


\section{Decreases in Productivity Due to Diversification}

One important way in which firms grow is through diversification (Berry, 1971). In Table 4 the coefficient on diversification is consistently positive, that is more diversification is associated with lower productivity. However, one reading of the model is that tax-breaks will lead to additional diversification, and that this will lower productivity within existing firms. The model in Section 2 does not describe multi-product firms specifically, but note that instead of a continuum of potential firms, we can imagine the specification describing one firm potentially producing a continuum of individual products.

Then, our expectation is that the IP will have induced firms to diversify, and thus that this is one way in which the policy led to lower average productivity. Column 3 reports the results of estimating a similar specification as in (6) except now we move our diversification measure to the LHS. We find that overall effect of the policy is negative, that is it increased diversification. Specifically, $\tau_{2}$ is significant at the $10 \%$ level and $\tau_{3}$ is insignificant but relatively precisely estimated. Testing the joint significance of $\sum \tau$ we are able to reject the null of no overall effect at all levels.

\subsection{Effects on Capital}

We have now seen that the policy was unsuccessful in encouraging productivity growth. We also seen that this is because as predicted by the theory, the new firms were less productive, and there were insufficient spillovers to offset this. We now consider the key mechanism by which firms were to be affected - cheaper capital. One might be contented, as governments often are in rich countries, with a policy that was at least successful in increasing capital levels and employment rates. We now see that the policy was also unsuccessful when judged on these criteria. Whilst, the provision of tax-breaks and subsidised loans did indeed increase capital levels, we find that this increased capital was normally used for investments other than new machinery necessary for greater or more efficient production, but rather in buildings or vehicles. Furthermore, we show that this can be understood as a hedge against 
inflation and changes in market conditions given rampant inflation and a dynamic but challenging business environment. We then show, that as suggested by the theory, the lack of investment in productive assets limited employment growth due to the policy.

\section{Direct Increases in Capital Due to Subsidies}

Both our intuition, and Section 2 suggest that treated firms should increase investment as the policy lowers the cost of capital. Column 4 of Table 5 reports the results of again estimating (6); but, now with firms' total book-capital on the left-hand side. The results suggest that firms in the treated sectors increased their capital levels, and that those treated by both arms of the policy did by slightly more; but, the geographical component of the treatment was associated with lower than average capital accumulation. This latter finding suggests that owners of firms preferred to take additional profits rather than reinvest. This might explain the results in Column 2 of Table 4 that the tax-break discouraged capital accumulation. This suggests that the subsidised loan programme that was a large part of the sectoral treatment was more effective at increasing capital levels than the taxbreaks. Testing the overall effect of the policy we can rule out that the policy did not increase capital levels, and thus on this basis may be judged as successful.

\section{Increases in Capital are Not Invested in Machinery}

Column 5 reports that despite the increases in Capital there were no overall effects on the Marginal Product of Capital; this is surprising as we would expect that a large increase in the capital stock should be reflected in a decrease, other things equal, in the marginal product. ${ }^{11}$ Column 6 reports estimates with the ratio of machinery to overall capital on the left hand side and documents that the sectoral treatment, led to a decrease in this ratio. This implies that new investments occasioned by the policy were in other forms of capital such as buildings and vehicles.

\footnotetext{
${ }^{11}$ This results also suggests that the policy is not encouraging growth by reallocating capital. If it were we would expect a large positive and significant coefficient here.
} 
Why might firms prefer not to invest in additional machinery? One explanation is that whilst they are keen to benefit from the subsidised loan, especially as high-inflation rates mean the real interest rate is negative, that they adopt a portfolio approach and choose to diversify their risk. By buying buildings and vehicles they are investing in assets that whilst offering a comparatively low return are weakly correlated with the profitability of their current product lines. Such a strategy makes most sense, however, if a firm is particularly uncertain about its future. One feature of the business environment for the firms we study is rapidly changing input prices and shifting demand. It also explains why the additional tax-breaks reduced capital levels - entrepreneurs used them as an opportunity to reduce the share of their wealth accounted for by their business. They instead took the funds as additional profits or reinvested in vehicles, for instance. The consequences of uncertainty about the future are magnified by the lack of of an effective bankruptcy procedure or a system of limited companies, meaning individuals are disinclined to take risks with borrowed capital. ${ }^{12}$

We take the hypothesis that the lack of productive investment is due to uncertainty to the data by calculating firm-year specific 'terms of trade' indices. Specifically, we calculate a price index for the input prices for each of the four best selling products, as well as a price index for their sales price. We define the 'terms of trade' as the ratio of the sum of these indices across the four products:

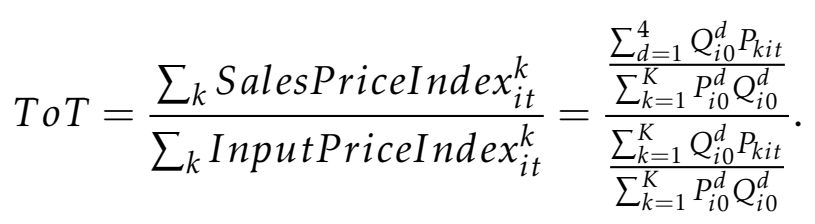

We do not adjust for quantities sold of these products to avoid potential endogeneity bias due to responses in production decisions due to changes in prices or vice-versa. We then estimate the following regression:

\footnotetext{
${ }^{12}$ As discussed by Lencho (2008), Ethiopian Law does provide a Bankruptcy procedure; but, the law has rarely been applied since 1960, and most lawyers are unfamiliar with it.
} 


$$
\ln (\text { machinery })=\beta \ln (\text { bookcapital })+\gamma \ln (T o T)+\mu_{i}+\epsilon_{i t} .
$$

The results are reported in Column 7. In line with our hypothesis we find that the ratio of capital in machines, etc., to total book capital is higher when the 'terms of trade' of a particular firm are higher. This highlights the challenges in designing successful IP - this behaviour is the upshot of several interrelated features of the particular context. Firstly, the high-growth high-inflation environment means that firms will seek to avoid holding cash whilst being willing to incur debt. Second, entrepreneurs will be more risk-averse due to the lack of effective bankruptcy protection. Finally, the absence of a well-developed financial services sector means that firms are unable to diversify, through acquisition, for example; thus, we get the accumulation of unproductive capital. However, these three factors are not unique to Ethiopia and neither, therefore, are the difficulties they suggest in the encouragement of investment.

\subsection{Effects on Employment}

The final outcome variable we consider is employment. The theoretical framework discussed above suggests that the firm-level effects of the IP on employment will depend on the relative magnitudes of the substitution and scale effects. Column 8 of Table 5 shows that there was no overall effect of the policy on employment. Again, we observe a negative effect of the geographical treatment, whether this reflects the failure of the tax-breaks to lead to additional capital accumulation is unclear. But, the positive and significant coefficient on (log) Total Book Capital suggests that this may be the case.

\section{The Cost of the Policy}

Rigorous policy evaluation techniques are by now routinely applied to assessing the effectiveness of different forms of aid at both a mac- 
roeconomic level, and also at the level of individual policies. Many development agencies and charities are committed to funding projects only based on evidence that they represent value for money. This suggests that IP should be evaluated on a similar benefit-cost basis. Given that we find little evidence of any positive effects of the policy, we could assume the policy had no benefits and focus on its costs. Instead, more conservatively, we prefer to assume the policy had the maximum plausible impact - the maximum of the $99 \%$ confidence interval of each of $\tau_{1}, \tau_{2}, \tau_{3}$. Thus, we evaluate the policy on the premise, that contrary to our results, it achieved an $83 \%$ increase in TFP. We also take into account the increase in the tax base due to additional entry of firms due to the policy. We do this by comparing the number of firms that entered in treated sectors to untreated sectors and use the difference as the number of firms caused by the policy. Again conservatively, we assume that all of the additional new firms in treated sectors are because of the policy. Following the the arguments in Section 2, and the results in the previous section, we assume that the least productive entrants are those induced by the policy. Thus, following the notation in Section 2, the profit of firm $i$ is $\Pi_{i}$. Denote the set of existing firms as $X$ and the set of additional entering firms as $E$ benefits in year $t, B_{t}$ are given by:

$$
B_{t}=T_{1}^{t}\left\{\sum_{i \in X} \Pi_{i t}-\frac{\sum_{i \in X} \Pi_{i t}}{1+\Phi^{-1}(0.995)\left(\tau_{1}+\tau_{2}+\tau_{3}\right)}+\sum_{i \in E} \Pi_{i t}\right\}
$$

where $T_{1}$ is the tax rate for firms treated by the policy and $T_{0}$ is the taxrate without it. We take a similarly conservative approach to the costs of the policy. We focus only on the loss of tax-revenue although this focus will understate the cost of the policy substantially as it ignores the costs of concessionary loans and the investment in sector specific training and technology transfer programmes. In particular, the costs of the loans will be substantial, given real interest rates were far below zero. We ignore both of these other costs as the cost of the loans will depend on future delinquency rates as well as future inflation, and there is no data on the costs of training and technology transfer. Costs are given by the 
loss of tax revenues on existing firms:

$$
C_{t}=\left(T_{0}-T_{1}\right) \sum_{i \in X} \Pi_{i t} .
$$

Figure 3: The Tax Costs of the Policy

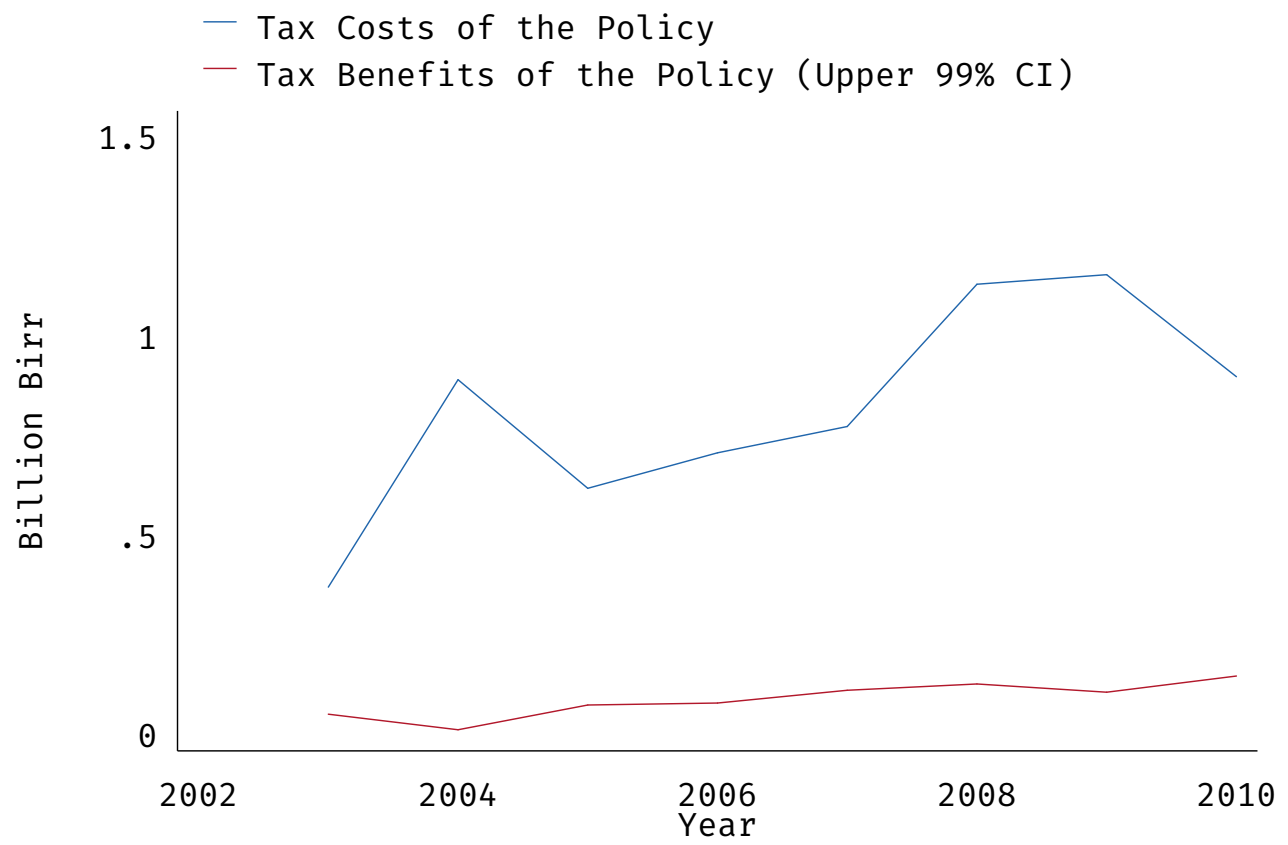

Figure 3 plots the lost tax receipts due to the policy - the blue line - and the additional tax due to TFP growth and firm entry - the red line -by year. The cost ranges from $\$ 39.4$ Million (358 Million Birr) to over \$121 Million (1100 Million Birr). Put differently, the average cost over the period was $0.5 \%$ of GDP or $5 \%$ of total Government spending. The benefits, meanwhile, even taken at the 99\% Confidence Interval, are less than $10 \%$ of the costs. Given that the manufacturing sector only accounts for $5 \%$ of Ethiopian GDP and that these numbers are very much lower bounds on the costs and upper bounds on the benefits, this is a substantial stimulus. This highlights the high-stakes nature of IP: whilst potentially transformative the costs are also substantial, both in fiscal terms, and also in terms of investments in health, education, and/or infrastructure forgone. Given this scale, it is hard to credit 
the lack of success of Ethiopia's development strategy to a lack of ambition or insufficient courage. Arguments to the contrary - that suggest that the push in the big push we study is insufficient - are hard to sustain. Certainly, given that we have documented the Ethiopian manufacturing sector's limited ability to absorb additional investment, spending substantially more on a bigger push premised on a belief that a larger stimulus would somehow be more easily absorbed would incarnate a substantial risk.

\section{Conclusion}

Industrial policy is ubiquitous both in more and less developed countries. But its goal in rich countries, tacitly the redirection of economic activity to poorer populations and regions, is easier to achieve than those of accelerated or sustained growth in LDCs. One reason for this is that tax-breaks or subsidised loans, designed to encourage investment, will encourage entry by previously non-viable firms. On the other hand agglomeration externalities, for instance, may lead to a virtuous upwards spiral. To investigate this possibility, this paper analysed the causal effects of a policy typical of modern IP in LDCs. Exploiting detailed firm-level data for the universe of Ethiopian manufacturing firms, we find that the policy was ineffective in raising productivity. Any gains in productivity due to the policy were more than offset by the lower quality of entering firms.

It is often supposed that manufacturing firms in LDCs are capitalstarved, and thus reducing the cost of capital would see rapid improvements. This also is not the case in the context we study. We found that one key reason for this is that firms are reluctant to invest in additional machinery, preferring instead to invest in assets only likely to be indirectly productive, such as office-blocks or vehicles. This would seem partly a response to rapid and variable inflation, which might make any given investment unprofitable. The lack of effective bankruptcy protection, only informal ownership of land, and acute shortages of skilled labour are also likely to be impediments to investment. One conclusion is, therefore, that the design of better IP in 
the future might involve more precisely targeted policies. An alternative conclusion is that rigorous programme-evaluation of a pilot scheme may be appropriate before such a large-scale policy is introduced.

The challenges faced by policy-makers in designing IP for Ethiopia and elsewhere reveal why previous, aggregate-based, studies have been largely inconclusive. The application of the approach of this paper to similar policies in other LDCs, like the accumulation of knowledge for richer countries, would allow the identification of what makes for successful IP in LDCs more generally, and which aspects of the policy's failure are particular to Ethiopia. 
Table 2: Summary Statistics

\begin{tabular}{|c|c|c|c|c|c|}
\hline & Mean & SD & Min & Max & $\begin{array}{c}\text { Typical } \\
\text { Firm }\end{array}$ \\
\hline (log) One Product TFP & 4.02 & 2.73 & -6.72 & 14.90 & 4.52 \\
\hline Prod. Labour & 71.67 & 214.96 & 0 & $9,103.5$ & 72.5 \\
\hline Employees (FTE) & 140.94 & 396.25 & 0 & 15,823 & 113.25 \\
\hline Paid-Up Capital \$ (Br ) & $\begin{array}{l}0.48 \\
(4.4)\end{array}$ & $\begin{array}{l}1.18 \\
(10.7)\end{array}$ & $\begin{array}{c}0.0 \\
(0.0)\end{array}$ & $11.0(100)$ & $0.44(3.99)$ \\
\hline Book Value of Machinery $\$(\mathrm{Br})$ & $0.19(1.7)$ & $0.72(6.5)$ & $0(0)$ & $\begin{array}{c}21.1 \\
(191.8)\end{array}$ & $0.08(0.7)$ \\
\hline Competition & 0.18 & 0.19 & 0.02 & 1 & 0.3 \\
\hline Product Diversification & 0.18 & 0.12 & 0 & 1.5 & 0.42 \\
\hline Government Owned & 0.09 & 0.29 & 0 & 1 & 0 \\
\hline Age & 18.57 & 15.65 & 0 & 99 & 20 \\
\hline Total Value of Intermediate & 0.67 & 1.64 & 0 & 14.40 & 0.23 \\
\hline Inputs $\$(\mathrm{Br})$ & $(6.1)$ & $(14.9)$ & $0(0$ & $(130.94)$ & $(2.07)$ \\
\hline $\begin{array}{l}\text { Investment in Fixed Assets } \$ \\
(\mathrm{Br})\end{array}$ & $\begin{array}{l}0.21 \\
(1.9)\end{array}$ & $\begin{array}{c}0.836 \\
(7.6)\end{array}$ & $0(0)$ & $\begin{array}{c}21.26 \\
(193.23)\end{array}$ & $0(0.02)$ \\
\hline Value of Output $\$(\mathrm{Br})$ & $\begin{array}{c}1.84 \\
(16.7)\end{array}$ & $4.41(40.1)$ & $0(0)$ & $\begin{array}{c}40.1 \\
(364.5)\end{array}$ & $1.52(13.8)$ \\
\hline
\end{tabular}

Monetary quantities in Millions of USD (Millions of Ethiopian Birr equivalents - denoted $\mathrm{Br}$ - in parentheses). All conversions use the 2006 USD:ETB exchange rate of 0.11 . This is the middle of the period we study, overall there is a downwards trend in the value of the Birr over the period. Competition and Diversification are calculated as described in Section 6. Production Labour is labour directly involved in production, as measured using temporary production workers (who account for almost all employment in our data). Government Owned is a dummy for government ownership.

Table 3: Production Function Estimates

\begin{tabular}{llccc}
\hline & $\begin{array}{c}(1) \\
\text { Olley - } \\
\text { Pakes }\end{array}$ & $\begin{array}{c}(2) \\
\text { Levinsohn } \\
- \text { Petrin }\end{array}$ & $\begin{array}{c}(3) \\
\text { GMM }\end{array}$ & $\begin{array}{c}(4) \\
\text { FE }\end{array}$ \\
\hline$(\log )$ Total Book Capital & $0.27^{* *}$ & $0.09^{* *}$ & $0.11^{* * *}$ & $0.09^{* * *}$ \\
& $(0.12)$ & $(0.04)$ & $(0.04)$ & $(0.02)$ \\
$(\log )$ Prod. Employment & $0.28^{* * *}$ & $0.15^{* * *}$ & $0.26^{* * *}$ & $0.32^{* * *}$ \\
& $(0.05)$ & $(0.02)$ & $(0.06)$ & $(0.04)$ \\
$(\log )$ Value of Inputs & $0.53^{* * *}$ & $0.53^{* * *}$ & $0.30^{* * *}$ & $0.21^{* * *}$ \\
& $(0.02)$ & $(0.15)$ & $(0.03)$ & $(0.02)$ \\
\hline$N$ & 6534 & 6478 & 6895 & 11753 \\
\hline OP 1-Product are the estimates obtained using the Olley and Pakes (1996) estimator and the \\
single largest product quantity index. Column 4 reports the results of the Levinsohn and Petrin \\
(2003) estimator, Column 5 an Arellano and Bond (1991) type GMM estimator, and Column 6 a \\
simple Fixed Effects estimator. Standard errors are in parentheses. The last two columns report \\
analytical standard errors clustered by firm; in the first two columns (clustered) standard errors \\
are obtained via the Bootstrap. * $p<0.10,{ }^{* *} p<0.05,{ }^{* * *} p<0.01$
\end{tabular}


Table 4: The Effects of the Policy on Total Factor Productivity

\begin{tabular}{|c|c|c|c|c|c|c|c|c|}
\hline & $\begin{array}{l}(1) \\
\text { OP }\end{array}$ & $\begin{array}{l}(2) \\
\text { New } \\
\text { Firms }\end{array}$ & $\begin{array}{c}(3) \\
\text { Single - } \\
\text { Product Firms }\end{array}$ & $\begin{array}{c}(4) \\
\text { Levinsohn } \\
\text { - Petrin }\end{array}$ & $\begin{array}{c}(5) \\
\text { GMM }\end{array}$ & $\begin{array}{l}\text { (6) } \\
\text { FE }\end{array}$ & $\begin{array}{l}(7) \\
\text { Private } \\
\text { Firms }\end{array}$ & $\begin{array}{l}(8) \\
\text { Government } \\
\text { Firms }\end{array}$ \\
\hline$\tau_{0}:$ Post-2002 & $\begin{array}{l}-0.04 \\
(0.10)\end{array}$ & & $\begin{array}{l}1.08^{* * *} \\
(0.28)\end{array}$ & $\begin{array}{l}0.28^{* * *} \\
0.04)\end{array}$ & $\begin{array}{c}-0.03 \\
(0.02)\end{array}$ & $\begin{array}{l}0.08^{* *} \\
(0.03)\end{array}$ & $\begin{array}{c}-0.00 \\
(0.11)\end{array}$ & $\begin{array}{c}-0.22 \\
(0.21)\end{array}$ \\
\hline$\tau_{1}:$ Sectoral Treatment & $\begin{array}{c}0.09 \\
(0.13)\end{array}$ & & $\begin{array}{l}-0.13 \\
(0.37)\end{array}$ & $\begin{array}{l}-0.01 \\
(0.05)\end{array}$ & $\begin{array}{l}-0.05 \\
(0.03)\end{array}$ & $\begin{array}{r}-0.03 \\
(0.04)\end{array}$ & $\begin{array}{c}0.15 \\
(0.15)\end{array}$ & $\begin{array}{l}-0.06 \\
(0.26)\end{array}$ \\
\hline$\tau_{2}:$ Geographic Treatment & $\begin{array}{c}0.00 \\
(0.11)\end{array}$ & & $\begin{array}{l}-0.43 \\
(0.38)\end{array}$ & $\begin{array}{l}-0.07^{*} \\
(0.04)\end{array}$ & $\begin{array}{c}0.05^{*} \\
(0.03)\end{array}$ & $\begin{array}{l}0.01 \\
(0.03)\end{array}$ & $\begin{array}{c}0.12 \\
(0.12)\end{array}$ & $\begin{array}{l}-0.39 \\
(0.27)\end{array}$ \\
\hline$\tau_{3}:$ Total Treatment & $\begin{array}{l}-0.12 \\
(0.20)\end{array}$ & & $\begin{array}{l}0.26 \\
(0.64)\end{array}$ & $\begin{array}{l}0.03 \\
(0.07)\end{array}$ & $\begin{array}{l}-0.11^{* *} \\
(0.05)\end{array}$ & $\begin{array}{l}-0.05 \\
(0.06)\end{array}$ & $\begin{array}{l}-0.23 \\
(0.23)\end{array}$ & $\begin{array}{l}0.24 \\
(0.39)\end{array}$ \\
\hline Compet $_{t s}$ & $\begin{array}{l}-0.44 \\
(0.33)\end{array}$ & & $\begin{array}{l}-0.70 \\
(0.79)\end{array}$ & $\begin{array}{l}-0.45^{* * * *} \\
(0.12)\end{array}$ & $\begin{array}{l}-0.30^{* * *} \\
(0.11)\end{array}$ & $\begin{array}{l}-0.28^{* *} \\
(0.11)\end{array}$ & $\begin{array}{l}-0.28 \\
(0.42)\end{array}$ & $\begin{array}{l}-0.84 \\
(0.55)\end{array}$ \\
\hline Divers $_{i t}$ & $\begin{array}{l}0.89^{* * *} \\
(0.33)\end{array}$ & & $\begin{array}{c}0.83 \\
(0.66)\end{array}$ & $\begin{array}{c}1.54^{* * *} \\
(0.20)\end{array}$ & $\begin{array}{l}0.93^{* * *} \\
(0.12)\end{array}$ & $\begin{array}{l}1.27^{* * * *} \\
(0.18)\end{array}$ & $\begin{array}{l}0.80^{*} \\
(0.46)\end{array}$ & $\begin{array}{c}0.69 \\
(0.54)\end{array}$ \\
\hline Age & $\begin{array}{c}0.00 \\
(0.00)\end{array}$ & & $\begin{array}{c}0.01 \\
(0.01)\end{array}$ & $\begin{array}{l}-0.00 \\
(0.00)\end{array}$ & $\begin{array}{c}0.00 \\
(0.00)\end{array}$ & $\begin{array}{l}-0.00 \\
(0.00)\end{array}$ & $\begin{array}{c}0.00 \\
(0.00)\end{array}$ & $\begin{array}{c}0.00 \\
(0.00)\end{array}$ \\
\hline Government Ownership & $\begin{array}{l}0.35^{* *} \\
(0.16)\end{array}$ & & $\begin{array}{l}1.21^{* *} \\
(0.57)\end{array}$ & $\begin{array}{l}-0.01 \\
(0.05)\end{array}$ & $\begin{array}{l}0.03 \\
(0.04)\end{array}$ & $\begin{array}{l}-0.06 \\
(0.05)\end{array}$ & & \\
\hline$\beta_{\tau_{1}}^{\Delta}$ & & $\begin{array}{l}-1.60^{* *} \\
(0.78)\end{array}$ & & & & & & \\
\hline$\beta_{\tau_{2}}^{\Delta}$ & & $\begin{array}{l}2.27^{* * *} \\
(0.67)\end{array}$ & & & & & & \\
\hline$\beta_{\tau_{3}}^{\Delta}$ & & $\begin{array}{l}-3.20^{* * *} \\
(1.01)\end{array}$ & & & & & & \\
\hline$N$ & 6117 & 10570 & 1061 & 7034 & 5518 & 7034 & 4806 & 1264 \\
\hline
\end{tabular}

$\tau_{0}, \tau_{1}, \tau_{2}$ and $\tau_{3}$ are the DDD coefficients defined in (6). Compet $t$ and Divers Cor $_{i t}$ are Herfindahl indices measuring competition and product diversification described in Section 6. Age reports how many years since the founding of the firm. Government Ownership is a dummy variable describing whether the firm is state owned. $\beta_{\tau_{3}}^{\Delta}, \beta_{\tau_{1}}^{\Delta}$, and $\beta_{\tau_{2}}^{\Delta}$ are the differences in the productivity of new firms entering due to the policy defined in (8). Standard errors in parentheses are clustered by firm. ${ }^{*} p<0.10,{ }^{* *} p<0.05,{ }^{* * *} p<0.01$ 
Table 5: Why Did the Policy have no effect?

\begin{tabular}{|c|c|c|c|c|c|c|c|c|}
\hline & $\begin{array}{l}(1) \\
\text { TFP }\end{array}$ & $\begin{array}{l}(2) \\
\text { TFP }\end{array}$ & $\begin{array}{c}(3) \\
\text { Divers }\end{array}$ & $\begin{array}{c}(4) \\
\text { Book Capital }\end{array}$ & $\begin{array}{c}(5) \\
\text { MPK }\end{array}$ & $\begin{array}{c}(6) \\
\text { Machinery } \\
\text { Capital }\end{array}$ & $\begin{array}{c}(7) \\
\text { Machinery }\end{array}$ & $\begin{array}{c}(8) \\
\text { Prod. Labour }\end{array}$ \\
\hline $\begin{array}{c}\text { Number of treated firms in Zone } \\
\text { (Standardized) }\end{array}$ & $\begin{array}{l}0.15^{*} \\
(0.08)\end{array}$ & $\begin{array}{c}0.08 \\
(0.06)\end{array}$ & & & & & & \\
\hline Compet ts & $\begin{array}{l}-0.53 \\
(0.35)\end{array}$ & $\begin{array}{l}-0.54^{*} \\
(0.30)\end{array}$ & & $\begin{array}{c}-0.45^{* *} \\
(0.22)\end{array}$ & $\begin{array}{l}-0.02 \\
(0.03)\end{array}$ & $\begin{array}{l}0.09^{* * *} \\
(0.02)\end{array}$ & & $\begin{array}{l}-0.10 \\
(0.09)\end{array}$ \\
\hline Divers $_{i t}$ & $\begin{array}{l}0.90^{* *} \\
(0.36)\end{array}$ & $\begin{array}{l}1.33^{* * * *} \\
(0.32)\end{array}$ & & & & & & \\
\hline Age & $\begin{array}{c}0.00 \\
(0.00)\end{array}$ & $\begin{array}{l}-0.00 \\
(0.00)\end{array}$ & $\begin{array}{l}-0.00 \\
(0.00)\end{array}$ & $\begin{array}{l}-0.00 \\
(0.00)\end{array}$ & $\begin{array}{c}0.00 \\
(0.00)\end{array}$ & $\begin{array}{c}0.00 \\
(0.00)\end{array}$ & & $\begin{array}{c}0.00 \\
(0.00)\end{array}$ \\
\hline$\tau_{0}:$ Post-2002 & & & $0.02^{* * * *}$ & $0.46^{* * * *}$ & -0.00 & $-0.17^{* * *}$ & & $0.16^{* * *}$ \\
\hline & & & $(0.01)$ & $(0.07)$ & $(0.00)$ & $(0.01)$ & & (0.03) \\
\hline$\tau_{1}:$ Sectoral Treatment & & & $\begin{array}{c}0.00 \\
(0.01)\end{array}$ & $\begin{array}{l}0.22^{* *} \\
(0.10)\end{array}$ & $\begin{array}{l}-0.00 \\
(0.01)\end{array}$ & $\begin{array}{c}-0.05^{* * *} \\
(0.01)\end{array}$ & & $\begin{array}{l}-0.03 \\
(0.04)\end{array}$ \\
\hline$\tau_{2}:$ Geographic Treatment & & & $-0.01^{*}$ & $-0.27^{* * *}$ & $0.01^{* *}$ & $0.07^{* * * *}$ & & $-0.08^{* * * *}$ \\
\hline & & & $(0.01)$ & $(0.08)$ & $(0.00)$ & $(0.01)$ & & $(0.03)$ \\
\hline$\tau_{3}:$ Total Treatment & & & -0.02 & $0.28^{*}$ & -0.01 & $-0.06^{* * *}$ & & 0.09 \\
\hline Government Ownership & & & -0.02 & $-0.96^{* * *}$ & -0.01 & -0.01 & & $0.48^{* * *}$ \\
\hline (log) Prod. Labour & & & $(0.01)$ & $\begin{array}{l}(0.15) \\
0.30^{* * *} \\
(0.03)\end{array}$ & $\begin{array}{l}(0.02) \\
0.00^{* * *} \\
(0.00)\end{array}$ & $(0.02)$ & & $(0.06)$ \\
\hline (log) Total Book Capital & & & & & & & $0.88^{* * *}$ & $0.05^{* * *}$ \\
\hline (log) Terms of Trade & & & & & & & $\begin{array}{l}0.00^{* *} \\
(0.00)\end{array}$ & (0.01) \\
\hline$N$ & 5564 & 11781 & 7235 & 12980 & 12980 & 12788 & 8653 & 12980 \\
\hline
\end{tabular}

Machinery is equipment directly used in the manufacturing process. Prod. Labour are workers directly involved in the production process. Terms of Trade is the ratio of firms sales price index to input price index as defined in (12). All other details are as for Table 4. 


\section{References}

Aghion, Philippe, Jing Cai, Mathias Dewatripont, Luosha Du, Ann Harrison, and Patrick Legros, "Industrial Policy and Competition," American Economic Journal: Macroeconomics, Oct 2015, 7 (4), 1-32.

Albouy, David, "The Unequal Geographic Burden of Federal Taxation," Journal of Political Economy, 2009, 117 (4), 635-667.

Arellano, Manuel and Stephen Bond, "Some Tests of Specification for Panel Data: Monte Carlo Evidence and an Application to Employment Equations," Review of Economic Studies, April 1991, 58 (2), 277-297.

Barro, Robert J., "Government Spending in a Simple Model of Endogeneous Growth," Journal of Political Economy, Oct 1990, 98 (5), S103-S125.

Berry, Charles H, "Corporate Growth and Diversification," Journal of Law and Economics, 1971, 14 (2), pp. 371-383.

Bertrand, Marianne, Esther Duflo, and Sendhil Mullainathan, "How Much Should We Trust Differences-in-Differences Estimates?," The Quarterly Journal of Economics, February 2004, 119 (1), 249-275.

Bigsten, Arne, Paul Collier, Stefan Dercon, Marcel Fafchamps, Bernard Gauthier, Jan Willem Gunning, Abena Oduro, Remco Oostendorp, Catherine Pattillo, Mans Soderbom, Francis Teal, and Albert Zeufack, "Do African Manufacturing Firms Learn from Exporting?," Journal of Development Studies, 2004, 40 (3), 115-141.

Blonigen, Bruce A., "Industrial Policy and Downstream Export Performance," The Economic Journal, 2015.

Bulow, Jeremy I and Lawrence H Summers, "A Theory of Dual Labor Markets with Application to Industrial Policy, Discrimination, and Keynesian Unemployment," Journal of Labor Economics, July 1986, 4 (3), 376-414.

Busso, Matias, Jesse Gregory, and Patrick Kline, "Assessing the Incidence and Efficiency of a Prominent Place Based Policy," American Economic Review, April 2013, 103 (2), 897-947.

Criscuolo, Chiara, Ralf Martin, Henry Overman, and John Van Reenen, "The Causal Effects of an Industrial Policy," Working Paper 17842, National Bureau of Economic Research February 2012.

_ , _ , , and _ , "CEP Discussion Paper No 1113 January 2012 The Causal Effects of an Industrial Policy," 2016, (1113). 
De Loecker, Jan, "Product Differentiation, Multiproduct Firms, and Estimating the Impact of Trade Liberalization on Productivity," Econometrica, 2011, 79 (5), 14071451.

_ , Pinelopi K. Goldberg, Amit K. Khandelwal, and Nina Pavcnik, "Prices, Markups, and Trade Reform," Econometrica, 2016, 84 (2), 445-510.

Deaton, Angus, "Panel Data from a Times Series of Cross-Sections," Journal of Econometrics, 1985, 30, 109-126.

Ferracci, Marc, Grégory Jolivet, and Gerard J. van den Berg, "Evidence of Treatment Spillovers Within Markets," Review of Economics and Statistics, dec 2014, 96 (5), 812 823.

Gobillon, Laurent, Thierry Magnac, and Harris Selod, "Do unemployed workers benefit from enterprise zones? The French experience," Journal of Public Economics, 2012, 96 (9-10), 881-892.

Goldberg, Pinelopi Koujianou, Amit Kumar Khandelwal, Nina Pavcnik, and Petia Topalova, "Imported Intermediate Inputs and Domestic Product Growth: Evidence from India,” The Quarterly Journal of Economics, 2010, 125 (November), 1727-1767.

Hall, Robert E and Dale W Jorgenson, "Tax Policy and Investment Behavior," The American Economic Review, 1967, 57 (3), pp. 391-414.

Harrison, Ann and Rodríguez-Clare, Andrés, Trade, Foreign Investment, and Industrial Policy for Developing Countries, Vol. 5 of Handbook of Development Economics, Elsevier,

Harrison, Ann E., "An Empirical Test of the Infant Industry Argument: Comment," American Economic Review, 1994, 84 (4), 1090-1095.

King, Mervyn A, "Taxation, corporate financial policy, and the cost of capital: A comment," Journal of Public Economics, 1975, 4 (3), 271-279.

Krueger, Anne and Baran Tuncer, "An Empirical Test of the Infant Industry Argument,” American Economic Review, 1982, 72 (4), 1142-1152.

Lencho, Taddese, "Ethiopian Bankruptcy Law: A Commentary (part I)," Journal of Ethiopian Law, 2008, XXII (2).

Levinsohn, James and Amil Petrin, "Production Functions Estimating to Control for Using Inputs Unobservables," The Review of Economic Studies, 2003, 70 (2), 317-341.

Marti, Darlan F and Ivan Ssenkubuge, "Industrialization And Industrial Policy in Africa: Is It a Policy Priority,” Technical Report 20, The South Center May 2009. 
Ministry of Finance and Economic Development, "Sustainable Development and Poverty Reduction Program," Technical Report, Ministry of Finance and Economic Development, Federal Democratic Republic of Ethiopia July 2002.

Moffitt, Robert, "Identification and estimation of dynamic models with a time series of repeated cross-sections," Journal of Econometrics, September 1993, 59 (1-2), 99-123.

Murphy, Kevin M, Andrei Shleifer, and Robert W Vishny, "Industrialization and the Big Push," The Journal of Political Economy, 1989, 97 (5), 1003-1026.

Neumark, David and Jed Kolko, "Do enterprise zones create jobs? Evidence from California's enterprise zone program," Journal of Urban Economics, July 2010, 68 (1), $1-19$.

Nunn, Nathan and Daniel Trefler, "The Structure of Tariffs and Long-Term Growth," American Economic Journal: Macroeconomics, 2010, 2 (4), 158-194.

Olley, G Steven and Ariel Pakes, "The Dynamics of Productivity in the Telecommunications Equipment Industry," Econometrica, November 1996, 64 (6), 1263-1297.

Rebelo, Sergio, "Long-Run Policy Analysis and Long-Run Growth," Journal of Political Economy, June 1991, 99 (3), 500-521.

Rodrik, Dani, “Industrial Policy: Don't Ask Why, Ask How," Middle East Development Journal, 2009, 1 (01), 1-29.

Rosenstein-Rodan, P. N., "Problems of Industrialisation of Eastern and South-Eastern Europe,” The Economic Journal, 1943, 53 (210), 202-211.

Ruane, Frances P, "Corporate income tax, investment grants, and the cost of capital," Journal of Public Economics, 1982, 17 (1), 103-109.

Siba, Eyerusalem, Mans Soderbom, Arne Bigsten, and Mulu Gebreeyesus, "Enterprise Agglomeration, Output Prices, and Physical Productivity: Firm-Level Evidence from Ethiopia," Working Paper Series, World Institute for Development Economic Research (UNU-WIDER) 2012.

Smith, Adam, An Inquiry into the Nature and Causes of Wealth of Nations, London: W. Strahan, 1776.

Topalova, Petia and Amit Khandelwal, "Trade Liberalization and Firm Productivity: The Case of India," Review of Economics and Statistics, 2011, 93 (August), 995-1009.

Verbeek, Marno, "Pseudo panels and repeated cross-sections," in Patrick Sevestre Làszlò Màtyàs, ed., The Econometrics of Panel Data: Fundamentals and Recent Developments in Theory and Practice, 3rd ed. number 46. In 'Advanced Studies in Theoretical and Applied Econometrics.', Springer, 2008, chapter 11, pp. 369-385. 
Table A1: Alternative Estimates of the Effects of the Policy on Productivity

\begin{tabular}{lcccc}
\hline & $(1)$ & $(2)$ & $(3)$ & $(4)$ \\
& OP & OP & OP & OP \\
\hline$\tau_{0}$ : Post-2002 & -0.04 & -0.03 & $7.16^{* * *}$ & $-0.51^{* *}$ \\
& $(0.16)$ & $(0.16)$ & $(0.68)$ & $(0.24)$ \\
$\tau_{1}$ : Sectoral Treatment & 0.24 & 0.23 & 0.24 & 0.27 \\
& $(0.15)$ & $(0.15)$ & $(0.16)$ & $(0.17)$ \\
$\tau_{2}$ : Geographic Treatment & -0.09 & -0.09 & -0.10 & -0.34 \\
& $(0.12)$ & $(0.12)$ & $(0.29)$ & $(0.23)$ \\
$\tau_{3}$ : Total Treatment & -0.00 & -0.03 & 0.04 & 0.15 \\
& $(0.20)$ & $(0.20)$ & $(0.24)$ & $(0.25)$ \\
Compet & -0.43 & -0.43 & -0.45 & -0.49 \\
& $(0.33)$ & $(0.33)$ & $(0.34)$ & $(0.35)$ \\
Divers & $1.12^{* * *}$ & $1.13^{* * *}$ & $1.12^{* * *}$ & $1.00^{* * *}$ \\
Age & $(0.35)$ & $(0.35)$ & $(0.35)$ & $(0.37)$ \\
& 0.00 & 0.00 & 0.00 & 0.00 \\
Government Ownership & $(0.00)$ & $(0.00)$ & $(0.00)$ & $(0.00)$ \\
& $0.28^{*}$ & $0.27^{*}$ & $0.32^{* * *}$ & $0.31^{*}$ \\
& $(0.16)$ & $(0.16)$ & $(0.16)$ & $(0.16)$ \\
\hline Year Effects & Yes & Yes & Yes & Yes \\
Geography Fixed Effects & No & Region & Region $\times$ Year & Zone \\
$N$ & 6122 & 6122 & 6122 & 5564 \\
\hline
\end{tabular}

Notes as for Table 4.

\section{A Additional Tables}


Table A2: Effects on Productivity by Treated Sector

\begin{tabular}{lcccc}
\hline & $(1)$ & $(2)$ & $(3)$ & $(4)$ \\
& Textiles & MLP & AgroIndustry & Construction \\
\hline$\tau_{0}$ : Post-2002 & -0.13 & -0.07 & $0.50^{* *}$ & -0.01 \\
& $(0.16)$ & $(0.22)$ & $(0.22)$ & $(0.32)$ \\
$\tau_{1}$ : Sectoral Treatment & -0.00 & -0.20 & -0.22 & -0.08 \\
& $(0.24)$ & $(0.25)$ & $(0.25)$ & $(0.36)$ \\
$\tau_{2}$ : Geographic Treatment & 0.04 & 0.05 & 0.01 & 0.29 \\
& $(0.33)$ & $(0.27)$ & $(0.30)$ & $(0.41)$ \\
$\tau_{3}$ : Total Treatment & -0.40 & -0.59 & -0.18 & -0.29 \\
Age & $(0.56)$ & $(0.45)$ & $(0.42)$ & $(0.56)$ \\
Government Ownership & $0.00^{* * *}$ & -0.00 & $-0.01^{* *}$ & 0.01 \\
& $(0.00)$ & $(0.01)$ & $(0.01)$ & $(0.01)$ \\
Compet & 0.14 & 0.29 & 0.22 & $0.67^{*}$ \\
& $(0.30)$ & $(0.37)$ & $(0.25)$ & $(0.40)$ \\
Divers $_{\text {it }}$ & -1.34 & -0.40 & $-1.15^{* *}$ & 0.02 \\
& $(0.85)$ & $(1.42)$ & $(0.53)$ & $(0.61)$ \\
& 0.63 & $2.89^{* * *}$ & $0.91^{*}$ & 1.56 \\
$N$ & $(0.90)$ & $(1.33)$ & $(0.50)$ & $(1.09)$ \\
\hline
\end{tabular}

Notes as for Table 4 .

Table A3: Effects on Book Capital by Treated Sector

\begin{tabular}{lcccc}
\hline & $(1)$ & $(2)$ & $(3)$ & $(4)$ \\
& Textiles & MLP & AgroIndustry & Construction \\
\hline$\tau_{0}$ : Post-2002 & 0.32 & 0.04 & 0.11 & 0.13 \\
$\tau_{1}$ : Sectoral Treatment & $(0.35)$ & $(0.12)$ & $(0.11)$ & $(0.29)$ \\
& 0.21 & $0.58^{* * *}$ & $0.47^{* *}$ & 0.57 \\
$\tau_{2}$ : Geographic Treatment & $(0.40)$ & $(0.15)$ & $(0.20)$ & $(0.39)$ \\
& $-0.88^{* *}$ & $0.31^{*}$ & $-0.57^{* *}$ & -0.74 \\
$\tau_{3}$ : Total Treatment & $(0.42)$ & $(0.16)$ & $(0.29)$ & $(0.53)$ \\
Age & 0.86 & $-0.54^{*}$ & 0.61 & 0.66 \\
& $(0.68)$ & $(0.28)$ & $(0.42)$ & $(0.83)$ \\
(log)Prod. Labour & -0.00 & 0.01 & -0.01 & -0.03 \\
Government Ownership & $(0.00)$ & $(0.01)$ & $(0.01)$ & $(0.02)$ \\
& 0.11 & $0.39^{* * *}$ & $0.43^{* * *}$ & $0.19^{*}$ \\
Compet & $(0.10)$ & $(0.11)$ & $(0.07)$ & $(0.11)$ \\
& $-0.67^{* *}$ & $-1.18^{* * *}$ & $-1.07^{* * *}$ & $-1.47^{* * *}$ \\
& $(0.29)$ & $(0.27)$ & $(0.28)$ & $(0.48)$ \\
$N$ & 1.21 & -0.98 & 0.19 & -0.97 \\
& $(1.27)$ & $(1.52)$ & $(0.58)$ & $(0.60)$ \\
\hline
\end{tabular}

Notes as for Table 5 . 
Table A4: Effects on Machinery by Treated Sector

\begin{tabular}{lcccc}
\hline & $(1)$ & $(2)$ & $(3)$ & $(4)$ \\
& Textiles & MLP & Agrolndustry & Construction \\
\hline$\tau_{0}$ : Post-2002 & 0.02 & -0.01 & -0.01 & -0.01 \\
& $(0.04)$ & $(0.02)$ & $(0.02)$ & $(0.04)$ \\
$\tau_{1}$ : Sectoral Treatment & $-0.25^{* * *}$ & $-0.19^{* * *}$ & $-0.18^{* * *}$ & $-0.17^{* * *}$ \\
& $(0.05)$ & $(0.04)$ & $(0.02)$ & $(0.05)$ \\
$\tau_{2}$ : Geographic Treatment & -0.03 & 0.03 & $0.06^{* *}$ & 0.03 \\
& $(0.06)$ & $(0.04)$ & $(0.03)$ & $(0.05)$ \\
$\tau_{3}$ : Total Treatment & 0.04 & 0.00 & -0.03 & -0.01 \\
Compet & $(0.09)$ & $(0.06)$ & $(0.04)$ & $(0.07)$ \\
Age & -0.18 & $0.42^{* * *}$ & 0.06 & $0.18^{* * *}$ \\
\multirow{2}{*}{ Government Ownership } & $(0.15)$ & $(0.13)$ & $(0.05)$ & $(0.04)$ \\
& -0.00 & 0.00 & 0.00 & $0.00^{*}$ \\
\hline$N$ & $(0.00)$ & $(0.00)$ & $(0.00)$ & $(0.00)$ \\
& $-0.06^{*}$ & 0.05 & 0.00 & -0.01 \\
& $(0.03)$ & $(0.05)$ & $(0.03)$ & $(0.06)$ \\
\hline
\end{tabular}

Notes as for Table 5.

Table A5: Effects on Employment by Treated Sector

\begin{tabular}{lcccc}
\hline & $(1)$ & $(2)$ & $(3)$ & $(4)$ \\
& Textiles & MLP & AgroIndustry & Construction \\
\hline$\tau_{0}$ : Post-2002 & $-0.22^{* * *}$ & -0.06 & 0.01 & 0.16 \\
& $(0.07)$ & $(0.11)$ & $(0.05)$ & $(0.11)$ \\
$\tau_{1}$ : Sectoral Treatment & $0.18^{*}$ & 0.01 & 0.02 & 0.00 \\
& $(0.11)$ & $(0.12)$ & $(0.07)$ & $(0.12)$ \\
$\tau_{2}$ : Geographic Treatment & 0.13 & -0.04 & -0.08 & -0.13 \\
& $(0.10)$ & $(0.12)$ & $(0.08)$ & $(0.12)$ \\
$\tau_{3}$ : Total Treatment & -0.21 & -0.05 & 0.03 & $0.40^{* *}$ \\
Age & $(0.18)$ & $(0.29)$ & $(0.12)$ & $(0.20)$ \\
& 0.00 & -0.01 & 0.00 & 0.00 \\
(log) Total Book Capital & $(0.00)$ & $(0.01)$ & $(0.00)$ & $(0.01)$ \\
& 0.02 & $0.18^{* *}$ & $0.06^{* * *}$ & $0.03^{*}$ \\
Government Ownership & $(0.02)$ & $(0.08)$ & $(0.01)$ & $(0.01)$ \\
& $0.34^{* *}$ & $0.64^{* * *}$ & $0.48^{* * *}$ & $0.74^{* * *}$ \\
Compet & $(0.15)$ & $(0.17)$ & $(0.08)$ & $(0.28)$ \\
& $-0.87^{*}$ & -0.25 & $-0.72^{* * *}$ & 0.18 \\
$N$ & $(0.47)$ & $(0.55)$ & $(0.19)$ & $(0.20)$ \\
\hline$N$ & 623 & 610 & 2240 & 1113
\end{tabular}

Notes as for Table 5. 


\title{
B Further Examples of Industrial Policy in Sub- Saharan Africa
}

\author{
Table A6: Industrial Policy in Sub-Saharan Africa
}

\begin{tabular}{ll}
\hline Country & Description \\
\hline Botswana & National: Policy aimed at enhancing productivity through highly skilled \\
& labour, export orientation and attraction of FDI. Trade: Customs Duty rebates \\
& on raw materials, tariff protection of infant industries and concessional \\
& import duty rebate and low tax rates. Sectoral: Motor Industry prioritized. \\
& Also textiles, foods and beverages benefited from support. Other: \\
& FDI attraction through tax incentives, human development, enterprise \\
& development and R\&D support. \\
Cameroon & National: Guided by 5 year plans from 1961-1991 that focus on both import \\
& substitution and export promotion. Trade: Free trade zones where 80 \\
& $\%$ of production is exported. Part of the Central African Economic and \\
& Monetary Community that guides the tariff rates. Sectoral: Textiles, wood, \\
& energy, some cereals, cocoa, coffee, shipbuilding, ICT and pharmaceuticals \\
& received exemption from personal income tax. Other: FDI attraction through \\
Investment promotion and infrastructure development. \\
National: Industrial Development Strategy in 2002 focussed on Agricultural \\
development led industrialization. Trade: Customs duty rebates and \\
Export promotion measures. Sectoral: Meat, Textile, Construction and \\
Agro-industry benefited from technology, financial and human capital \\
support. Other: Attraction of FDI through various incentives including tax \\
exemptions. \\
National: Broad Growth and Poverty Reduction strategy aimed at \\
competitiveness of private sector, human resource development and public \\
sector reform. Trade: Higher tariff rates for more processed goods like textile, \\
apparel, furniture and beverage. Part of ECOWAS customs union. Sectoral: \\
ICT is a big priority. Others include biotechnology, cassava, textiles, palm oil \\
and salt. Other: Established Institute of Industrial Research, FDI attracting \\
through tax holiday (also depending on location). \\
Ghana
\end{tabular}


Kenya National: 1996 Policy: "Industrial Transformation to the Year 2020" focussing on export orientation. Trade: Export Processing Zones and Export promotion council, duty remission facility. Part of EAC FTA. Firms in these zones benefit from tax holiday. Sectoral: Agro-industries, textile, coffee, tea, construction. Other: Investment Authority to attract FDI through tax holiday, Industrial Research and Development Institute.

Rwanda National: Included in three programs, Growth for Jobs and Exports, Vision 2020 and Governance focussing on infrastructure, reducing cost of doing business, promoting innovation and financial sector development. Trade: Higher Duty on more processed goods. Part of the EAC FTA that guides Duty rates. Sectoral: Information and Communication Technology supported through human capital, infrastructure. Coffee and tea also received support. Other: Rwanda investment and export promotion agency, one of the most open FDI regimes through exemption of corporate income tax.

South Africa National: Included in the "Accelerated and Shared Growth Initiative" focusing on manufacturing exports. This is Complemented by National Industrial Policy Framework. Trade: Export marketing and investment assistance, export credit incentive, export credit insurance and customs duty refunds. Sectoral: Capital equipment, transport equipment, automotive assembly, chemicals, plastics and pharmaceuticals, textile and footwear received support. Other: Government supports science and technology research, assistance on global value chain, clusters and efficiency.

Uganda National: National industrial policy included in "Medium Term Competitiveness Strategies" with the objectives of improving business environment. Trade: Fixed duty drawback scheme for exports. Member of EAC FTA that guides tariff bands. Sectoral: Promotion of linkages between ICT, construction, textile, agro processing and energy. Other: Infrastructure, financial sector, institutional and human development are part of the broader strategy. FDI attraction prioritized through tax exemptions.

\section{Specific Sector Support}

PASDEP prioritised industrial development in four sectors, and these sectors received support from the government to achieve more non-agricultural employment, investment and production. These sectors are the textile and garment sector; meat and leather producers; agro-industry, and the construction industry. The government has implemented specific measures in support of these industries since 2003/04. These sectors were chosen for their direct linkages to the agricultural sector, labour intensiveness and export potential. These priority sectors have been subject to several benchmarking exercises and the establishment of industry-wide targets. Notable 
targets in PASDEP were that by the end of 2009/10 the export earnings from the textile sector would reach USD 500 million as a result of investment in the sector worth USD 1.6 billion. The majority of the additional investment was planned to come from the private sector. However, the government also planned to invest jointly with foreign investors. For the meat and leather industries it was envisaged for that export earning would increase to USD 178 million by establishing 74 firms by 2009/10. These targets highlight the continuing strong role of the state envisaged during the PASDEP period. To achieve these specific targets a host of measures have been taken related to training, input market interventions, establishing sector development institutes, public private partnerships and the scaling up of sectoral pilot projects.

All four sectors were given priority access to foreign currency. As discussed in the main text, they also all had access to concessionary loans via The Development Bank of Ethiopia, a state owned bank established facilitate investment with loans up to 70 percent of the initial capital to private sector firms investing in the four treated sectors. Sector specific support included:

- Textiles: The government started textile engineering training program in one of the government universities (Bahirdar University). The first class graduated in 2002. In 2010 the government established the Ethiopian Textile Development Institute to organize all the support in one institution. The institute supports existing firms and entrants in the sector on selection of technology, negotiation, construction, erection and commissioning. It also provides practical training on technology and marketing.

- Leather and Leather Products: Additional export support via inclusion in the Prime Minister's Committee to Promote Exports. Also, similarly to the support provided to the textile sector, the Ethiopian Leather Industry Development Institute was established in 2010.

- Agro-processing: Firms in the Agro-industry sector have access to cheaper leases for land.

- Construction: Other than the concessionary loans and priority access to foreign exchange the construction sector received little other specific support.

\section{The Number of Firms by Industrial Classi- fication}


Table A7: Number of Firms in 1996 and 2010 in each ISIC Category

\begin{tabular}{|c|c|c|c|}
\hline ISIC Classification & 1996 & 2010 & Treatment \\
\hline 1511 Production, processing and preserving of meat, fruit and veg & 6 & 9 & Treated (Agro) \\
\hline 1514 Manufacture of edible oil & 25 & 31 & Treated(Agro) \\
\hline 1520 Manufacture of dairy products & 1 & 20 & Treated(Agro) \\
\hline 1531 Manufacture of flour & 17 & 154 & Treated(Agro) \\
\hline 1533 Manufacture of animal feed & 2 & 6 & Treated(Agro) \\
\hline 1541 Manufacture of bakery & 63 & 142 & Treated(Agro) \\
\hline 1542 Manufacture of sugar and confectionary & 5 & 17 & Treated(Agro) \\
\hline 1544 Manufacture of pasta and macaroni & 3 & 13 & Treated(Agro) \\
\hline 1549 Manufacture of food NEC & 4 & 8 & Treated(Agro) \\
\hline 1551 Distilling rectifying and blending of spirit & 6 & 12 & Treated(Agro) \\
\hline 1552 Manufacture of wine & 1 & 1 & Treated(Agro) \\
\hline 1553 Malt liquors and malt & 5 & 7 & Treated(Agro) \\
\hline 1554 Manufacture of soft drinks & 6 & 21 & Not Treated \\
\hline 1600 Manufacture of tobacco & 1 & 1 & Not Treated \\
\hline 1710 Spinning, weaving and finishing & 18 & 28 & Treated(Textile) \\
\hline 1723 Manufacture of cordage rope and twine & 3 & 1 & Treated(Textile) \\
\hline 1730 Knitting mills & 9 & 0 & Treated(Textile) \\
\hline 1810 Manufacture of wearing apparel except fur & 23 & 40 & Treated(Textile) \\
\hline 1910 Tanning and dressing of leather & 8 & 27 & Treated(Leather) \\
\hline 1920 Manufacture of footwear & 50 & 66 & Treated(Leather) \\
\hline 2000 Manufacture wood and wood products & 25 & 41 & Treated(Agro) \\
\hline 2100 Manufacture of paper and paper products & 5 & 17 & Treated(Agro) \\
\hline 2200 Publishing and printing services & 27 & 65 & Not Treated \\
\hline 2411 Manufacture of basic chemicals except fertilizers & 2 & 19 & Not Treated \\
\hline 2422 Manufacture of paints varnishes & 5 & 8 & Not Treated \\
\hline 2423 Manufacture of pharmaceutical, medicinal & 1 & 9 & Not Treated \\
\hline 2424 Manufacture of soap detergents, perfumes.. & 20 & 33 & Not Treated \\
\hline 2429 Manufacture of chemical products NEC & 3 & 4 & Not Treated \\
\hline 2510 Manufacture of rubber & 4 & 3 & Not Treated \\
\hline 2520 Manufacture of plastics & 10 & 107 & Not Treated \\
\hline 2610 Manufacture of glass and glass products & 2 & 2 & Not Treated \\
\hline 2693 Manufacture of structural clay products & 7 & 4 & Not Treated \\
\hline 2694 Manufacture of cement,lime and plaster & 6 & 20 & Treated(Constr.) \\
\hline 2695 Manufacture of articles of concrete, cement & 62 & 223 & Treated(Constr.) \\
\hline 2699 Manufacture of non-metallic NEC & 3 & 136 & Not Treated \\
\hline 2710 Manufacture of basic iron and steel & 1 & 28 & Not Treated \\
\hline 2811 Manufacture of structural metal products & 27 & 99 & Treated(Constr.) \\
\hline 2892 Manufacture of cutlery hand tools & 0 & 6 & Not Treated \\
\hline 2893 Manufacture of other fabricated metal products & 4 & 3 & Not Treated \\
\hline 2899 Manufacture of pumps,compressors, valves and taps & 5 & 8 & Not Treated \\
\hline 2914 Manufacture of ovens & 5 & 12 & Not Treated \\
\hline 2925 Manufacture of other general purpose machinery & 6 & 1 & Not Treated \\
\hline 3140 Manufacture of batteries & 0 & 1 & Not Treated \\
\hline 3420 Manufacture of bodies for motor vehicles & 7 & 8 & Not Treated \\
\hline 3430 Manufacture of parts and accessaries & 1 & 1 & Not Treated \\
\hline 3610 Manufacture of furniture & 62 & 227 & Not Treated \\
\hline
\end{tabular}

